\title{
ESTUDOS SOBRE A ONTOGENIA E ALGUNS CARACTERES DO FEIJOEIRO (Phaseolus vurgaris L.) A PARTIR DE SEMENTES IRRADIADAS COM NEUTRONS RÄPIDOS
}

MARIA LUCIA STEAGALL

Orientador: AKIHIKO ANDO

Tese apresentada à Escola Superior de Agricultura "Luiz de Queiroz", da Universidade de São Paulo, para obtenção do título de Doutor em Agronomia. Área de Concentração: Genética e Melhoramento de Plantas

\author{
PIRACICABA \\ Es tado de São Paulo-Brasil \\ Maio, 1982
}


Aos meus pais, de quem muito me orgulho de ser filha e pela felicidade que me dão por existirem;

As minhas irmãs

$e$ demais familiares, 
Ao Prof. Dr. Akihiko Ando,

Ao Prof. Or. José Theophilo do Amaral Gurgel,

Ao Sr. Antonio de oliveira (in memoriom),

OFEREÇO 


\section{AGRADECIMENTOS}

Minha imensa gratidão a todos aqueles que de alguma forma contribuíram para a realização deste trabalho e, em especial a:

- Prof. Dr. Akihiko Ando

- Profa. Dra. Maria Ruth Buzzato Alleoni

- Prof. Dr. Ermesto Paterniani

- Prof. Dr. Augusto Tulmann Neto

- Prof. Dr. José Otāvio Machado Menten

- Prof. Dr. Fabrizio D'Ayala Valva

- Profa. Marlene Kiyoni Hosaki

- Professores do Departomento de Genética

- Funcionários do Departamento de Genética, em particular à: Sra. Eisa A.A. César, Sra. Terezinha.de Jesus Lodovico Barrete, Sr. Alaor de Oliveira, Sr. Antonio Capobianco, Sr. Humberto Gorga Filho, e Sr. José Broglio.

- Sr. Armando Adilson de Oliveira

- Amigos e colegas do Curso de Pós-Graduação

- Laboratório de Seibersdorf da Agência Intermacional de Energia Atômica, Viena, Austria, na pessoa do Dr. Helmut Brunner

- CNPq (Conselho Nacional de Desenvolvimento Cientifico e Tecnológico)

- Departomento de Biologia Geral da Universidade Federal de Goiás

- Meus pais, Angela Rossin Steagall e Eduardo Steagall 


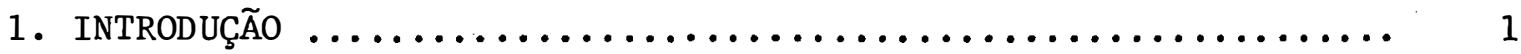

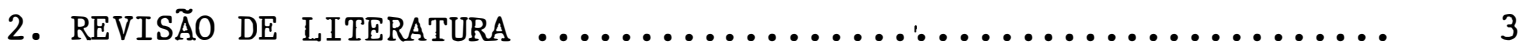

2.1. Generalidades sobre a indução de mutações no melhoramen

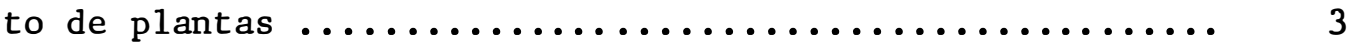

2.2. Fertilidade de plantas $\mathrm{M}_{1} \ldots \ldots \ldots \ldots \ldots \ldots \ldots \ldots \ldots \ldots \ldots \ldots$

2.3. Coloração do tegumento e sua relação com a coloração do

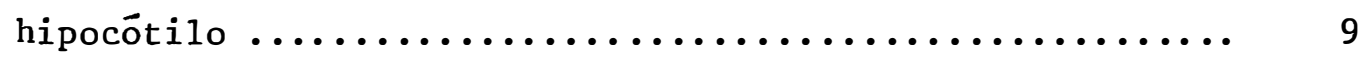

2.4. Quimerismo em 1 lantas $\ldots \ldots \ldots \ldots \ldots \ldots \ldots \ldots \ldots \ldots \ldots \ldots \ldots$

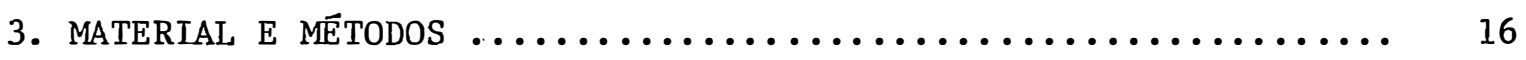

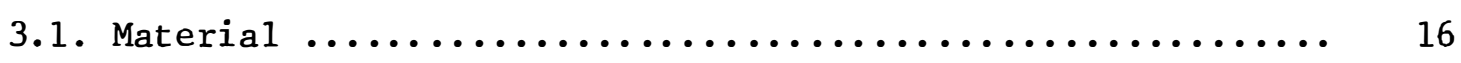

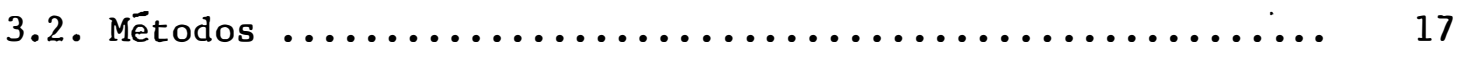

3.2.1. Tratamentos mutagênicos .................. 17

3.2.2. Execução experimentai $\ldots \ldots \ldots \ldots \ldots \ldots \ldots \ldots \ldots . \ldots \ldots$

3.2.3. Classificação das mutações .................. 19

3.2.4. Fertilidade das plantas $M_{1} \ldots \ldots \ldots \ldots \ldots \ldots \ldots \ldots . \ldots \ldots$

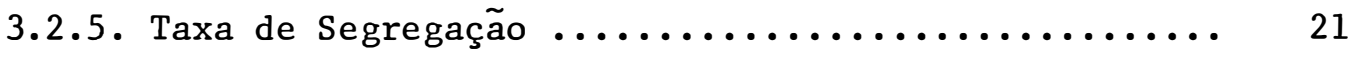

3.2.6. Número de células iniciais presentes no embrião das sementes e estrutura quimérica das plantas $M_{1} \ldots \ldots 22$

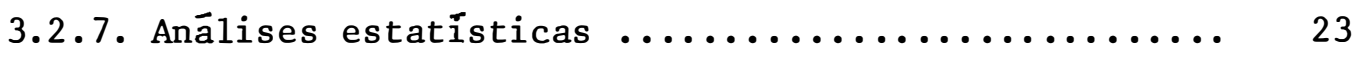

3.2.7.1. Fertilidade das plantas $M_{1} \ldots \ldots \ldots \ldots \ldots . \ldots . \ldots 23$

3.2.7.2. Germinação e sobrevivência na geração $\mathrm{M}_{2} \cdot 24$

3.2.7.3. Germinação na geração $M_{3} \ldots \ldots \ldots \ldots \ldots . \ldots 24$

3.2.7.4. Frequências de mutações em plântulas $M_{3} \ldots 25$

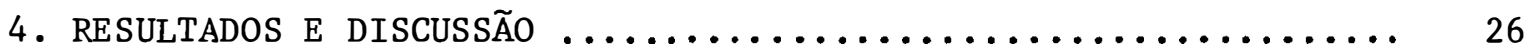

4.1. Fertilidade das plantas $M_{1} \ldots \ldots \ldots \ldots \ldots \ldots \ldots \ldots \ldots . \ldots \ldots$

4.2. Germinação das sementes e sobrevivência das plantas na

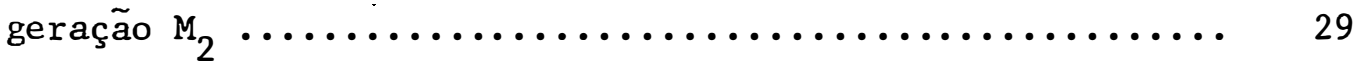

4.3. Germinação das sementes na geração $M_{3} \ldots \ldots \ldots \ldots \ldots \ldots \ldots \ldots$

4.4. Frequências de mutações na geração $M_{3} \ldots \ldots \ldots \ldots \ldots \ldots \ldots$ 
4.5. Taxas de segregação, núme ro de células iniciais presentes no embrião e estrutura quimérica das plantas $\mathrm{M}_{1} \ldots \ldots \ldots$

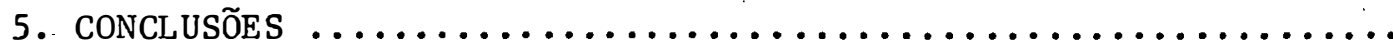

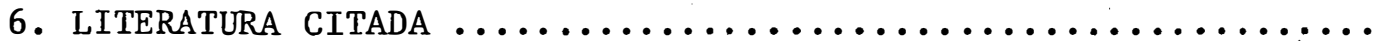


8 - Número de: plantas $M_{1}$ e $M_{2}$ estudadas, sementes $M_{3}$ semeadas e percentagem de germinação; e número de mutantes e frequên cias de mutações para a coloração do hipocótilo, clorofíli cas e morfológicas e frequência de mutação total dos diferentes tratamentos com neutrons rápidos $\ldots \ldots \ldots \ldots \ldots \ldots$

9 - Valores de $\chi^{2}$ obtidos pelo teste de independênciá, entre to dos os tratamentos tomados 2 a 2, para as frequências de mutações, determinadas na geração $M_{3} \ldots \ldots \ldots \ldots \ldots \ldots$

10 - Taxas de segregação para todos os tipos de mutações efetua dos em. plântulas $M_{3}$, nos tratamentos com 3 dosagens de ne $\underline{u}$

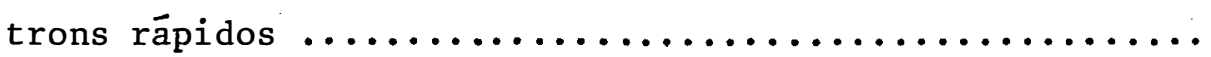

11 - Taxas de segregação determinadas em plântulas $M_{3}$ nas clas ses de mutações observadas nos diferentes tratamentos com

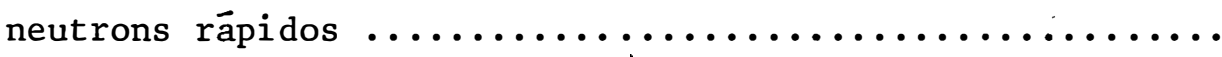

12 - Número de plantas $M_{1}$ e $M_{2}$ estudadas, sementes $M_{3}$ semeadas, percentagem de germinação, número de mutantes e taxas de segregação para todos os tipos' de mutações considerados em conjunto, nos diferentes tratamentos com neutrons rāpidos.

13 - Taxa de segregação e número de células iniciais para classes de mutações consideradas em diferentes categorias de plantas $M_{1}$, em duas dosagens de neutrons rápidos ........ 
-viii-

Tabela

Pägina

14 - Número médio de células iniciais para os diferentes tipos de mutações com 2 dosagens de neutrons rápidos .. 


\section{LISTA DE FIGURAS}

Figura

Pāgina

1 - Germinação das sementes e sobrevivência das plantas na ge ração $M_{2}$ em relação às dosagens de neutrons rāpidos apli-

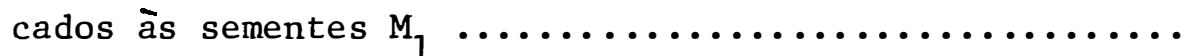

2 - Germinação das sementes $M_{3}$ em relação às dosagens de neutrons räpidos aplicadas às sementes $M_{1} \ldots \ldots \ldots \ldots \ldots \ldots$

3 - Taxas de mutações determinadas na geração $M_{3}$, para as clas ses de mutações: morfológica, de clorofila e para hipocó-

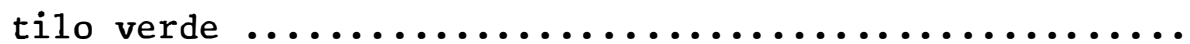

4 - Taxas de mutações determinadas na geração $M_{3}$ para todos os tipos de mutações observadas ..................... 40

5 - Mutante para coloração rosa do hipocótilo ............. 44

6 - Mutante albino ............................ 44

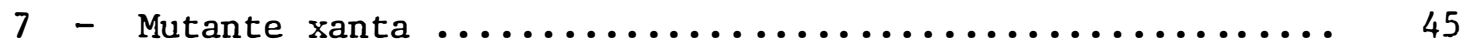

8 - Mutante com folhas primārias albinas e hipocótilo com co loração verde normal $\ldots \ldots \ldots \ldots \ldots \ldots \ldots \ldots \ldots \ldots \ldots \ldots$

9 - Mutante rosa-verde ......................... 47

10 - Mutante verde-xanta $\ldots \ldots \ldots \ldots \ldots \ldots \ldots \ldots \ldots \ldots \ldots \ldots \ldots$

11 - Mutante maculada ........................ 48 
12 - Mutante com folhas de coloração verde normal, albinas e albinas com manchas verdes e verdes com manchas brancas.

13 - Vista geral do ensaio, instalado em casa de vegetação,mos

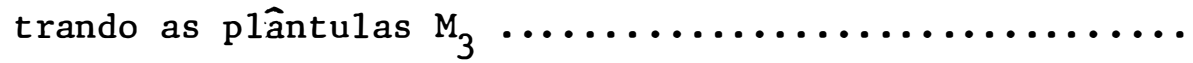

14 - Representação esquemática da anāiise topogrāfica da planta $M_{1}$ no 3.21, mostrando sementes $M_{2}$ heterozigotas e homo zigotas dominantes para o carāter mutante hipocótilo

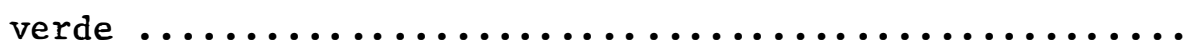

15 Representação esquemātica da anālise topogrāfica da planta $M_{1}$ no 3.21, mostrando sementes $M_{2}$ heterozigotas e homo zigotas dominantes para a mutação verde-xanta $\ldots . . \ldots \ldots$

16 - Representação esquemática da anālise topogrāica da planta $M_{1}$ no 3.24, mostrando sementes $M_{2}$ heterozigotas e homo zigotas dominantes para a mutação morfológica trifoliar (3 folhas primärias) $\ldots \ldots \ldots \ldots \ldots \ldots \ldots \ldots \ldots \ldots \ldots$

17 - Representação esquemática da anālise topogräfica da planta $M_{1}$ no 3.24, mostrando sementes $M_{2}$ heterozigotas e homo zigotas dominantes para o carāter mutante viridis ......

18 - Representação esquemática da anālise topográfica da planta $M_{1}$ no 3.24, mostrando sementes $M_{2}$ heterozigotas e homozi gotas dominantes para o carāter mutante hipocótilo verde ... 
19 - Representação esquemātica da anālise topogrāfica da planta $M_{1}$ no 5.05, mostrando sementes $M_{2}$ heterozigotas e homo zigotas dominantes, para o carâter mutante hipocótilo

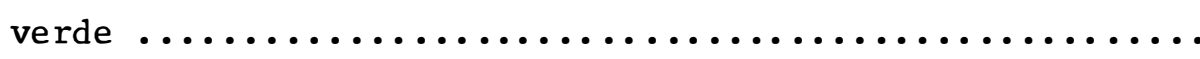

20 - Representação esquemática da análise topográfica da planta $M_{1}$ n 9.05 , mostrando sementes $M_{2}$ heterozigotas e homo zigotas dominantes, para o carāter mutante hipocótilo verde-escuro $\ldots \ldots \ldots \ldots \ldots \ldots \ldots \ldots \ldots \ldots \ldots \ldots \ldots \ldots \ldots \ldots \ldots \ldots$

21 - Representação esquemática da análise topográfica da planta $M_{1}$ no 5.14, mostrando sementes $M_{2}$ heterozigotas e homo zigotas dominantes, para ocaráter mutante trifoliar .....

22 - Representação esquemática da análise topográfica da planta $M_{1}$ no 5.14, mostrando sementes $M_{2}$ heterozigotas e homo zigotas dominantes, para o carāter mutante xanta .......

23 - Representação esquemātica da anālise topogrāfica da planta $M_{1}$ no 5.14, mostrando sementes $M_{2}$ heterozigotas e homo zigotas dominantes para o carāter mutante hipocótilo

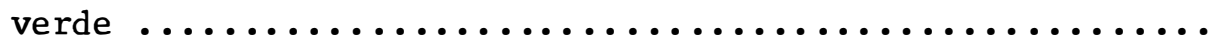


ESTUDOS SOBRE A ONTOGENIA E ALGUNS CARACTERES DO FEIJOEIRO (Phaseolus vulgaris L.) A PARTIR DE SEMENTES IRRADIADAS COM NEUTRONS RĀPIDOS

Maria Lücia Steagall

Akihiko Ando

Orientador

\section{RESUMO}

A finalidade principal deste trabalho foi investigar a onto genia em sementes de feijão comum (Phaseolus vulgaris L.), cultivar Costa Rica, usando-se como tratamentos mutagênicos, diferentes dosagens de neutrons rápidos. Utilizou-se os dados da contagem das mutações de clorofila, morfologia e coloração do hipocótilo, em progênies na geração $\mathrm{M}_{3}$ e, ta xas de segregação de heterozigotos determinadas em progênies na geração $\mathrm{M}_{2}$. A anālise topogräfica das plantas $M_{1}$ foi feita para localizar a posição das mutações dentro das inflorescências, o que permitiu verificar a condição qui mérica das plantas $\mathrm{M}_{1}$.

Estudos adicionais foram realizados pela determinação dos pa-

râmetros: fertilidade das plantas $M_{1}$, germinação das sementes e sobrevivên cia das plantas $M_{2}$, germinação das sementes $M_{3}$ e frequências de mutações determinadas na "geração $M_{3}$.

0s resultados mostraram que o tratamento com 2,0 krad de neutrons rápidos, foi mais eficiente do que com 1,0 krad, causando uma maior 
taxa de segregação que correspondeu a uma diminuição no nūmero de células iniciais.

A anālise topogräfica das plantas $M_{1}$ mostrou que um mesmo tipo de mutação apareceu em diversas ramificações primárias de uma planta, e que mais do que um tipo de mutação ocorreu numa mesma ramificação primária. Isso sugeriu que na formação de uma ramificação primária estão envol vidas mais de uma cêlula inicial e que todas as ramificações primárias de uma planta originam-se das mesmas células iniciais.

Considerando que as mutações aparecem ao acaso e, quando de terminadas pelos métodos convencionais, apresentam baixa frequência, os re sultados obtidos neste trabalho mostraram a ocorrência de números relativa mente altos de mutações por célula. 
STUDIES ON ONTOGENY AND SOME CHARACTERS IN BEANS (PhaseoZus vulgaris L.)

THROUGH THE SEEDS IRRADIATED WITH FAST NEUTRONS

Maria Lücia Steagall

Akihiko Ando

Adviser

\section{SUMMARY}

The principal purpose of the present study was to investigate the ontogeny of the seed of conmon beans (Phaseolus vulgaris L.), variety Costa Rica, irradiated with different doses of fast neutrons.

The characters analysed were chlorophyll, morphological and hypocotyl color mutations in the $\mathrm{M}_{3}$ generation. Segregation ratios of the heterozygous seeds for these mutations in the $\mathrm{M}_{2}$ generation were also considered. Topographical analysis of the $\mathrm{M}_{1}$ plants were made to elucidate the position of mutations within their inflorescences, which allowed to verify chimeric formation in the $M_{1}$ plants originated from the irradiated seeds.

Additional studies were carried out to observe the effects of fast neutrons on: fertility of the $\mathrm{M}_{1}$ plants, germination and survival of the $\mathrm{M}_{2}$ plants, germination and mutation frequencies in the $\mathrm{M}_{3}$ plants. 
neutrons was more effective than that with $1 \mathrm{krad}$, causing higher segregation ratios and consequent diminution of the initial cell number in the embryo.

The topographycal analyses of the $M_{1}$ plants showed that the same type of mutations occurred in various primary branches, and more than one type of mutation could be present in a single primary branch, indicating that a primary branch can be differentiated from more than one initial cell.

Considering that mutations occur at random and that mutation rates determined through conventional methods are relatively low, the results of the present work showed that relatively high mutation frequency per cell can be obtained by fast neutron irradiation. 


\section{INTRODUÇÃO}

0 gênero Phaseolus L. é composto por värias espécies, as quais são agrupadas em "formas asiāticas." :e "formas americanas". As "formas americanas" abrangem quatro espécies, das quais Phaseolus vulgaris L. é a mais cultivada. Na América Latina, esta espécie é plantada em grande escala, sendo que no Brasil foi sempre uma das culturas alimentares de maior importância, representando um dos principais produtos da dieta humana diária, so bretudo para a população de menor renda, que tem nessa leguminosa sua fonte básica de proteína.

A espécie Phaseolus vulgaris L. é amplamente distribuída através do mundo e apresenta grande variabilidade nos caracteres morfológicos e tipos ecológicos, formando um grande conjunto gênico em populações. Além disso, a autogamia e o ciclo vital curto são fatores que favorecem a realização de estudos genéticos nessa espécie que vem sendo estudada desde os tempos de MENDEL.

Em qualquer programa convencional de melhoramento de plantas, os métodos são alicerçados na variabilidade genética existente nas populações ou conseguida através da introdução de plantas de outras variedades e 
posterior recombinação seguindo a hibridação e seleção. Entretanto, a utilização de mutagênicos físicos e/ou químicos fornece mais uma alternativa para a criação ou aumento desta variabilidade. Portanto, atualmente, a indução de mutações tem sidoutilizada em värios países e, em alguns casos, com êxito, como uma técnica alternativa, ou às vezes como único recurso disponível no melhoramento das mais diversas culturas, principalmente em autógamas.

Desde que exịste uma grande reserva de variabilidade genética entre as diferentes espécies de feijoeiro, ē de grande interesse estudar quais os tipos e as frequências de mutantes que, realmente, são induzidos por radiações ionizantes e, principalmente, investigar se estas podem induzir certos tipos de mutações que são extremamente raras ou desconhecidas na população natural.

Alguns trabalhos efetuados, utilizando tanto os mutagênicos físicos como os químicos, têm demonstrado a importância do conhecimento da ontogenia da semente do feijoeiro para o melhoramento dessa cultura, por per mitir uma estimativa do tamanho amostragem necessāria para a detecção da má xima frequência de mutação.

0 presente trabalho teve como principal finalidade estudar a ontogenia em sementes de feijoeiro (Phaseolus vulgaris L.), cultivar Costa Rica, cujas sementes foram submetidas a tratamentos com diversas dosagens de neutrons rápidos. Esse estudo foi efetuado através das taxas de segrega ção para mutações de clorofila, morfologia e coloração do hipocótilo, verificadas na geração $M_{3}$. Além disso, procurou-se estabelecer a relação entre as diversas dosagens de radiação aplicadas às sementes e a germinação e sobrevivência na geração $M_{2}$, germinação na geração $M_{3}$ e a fertilidade das plan tas $M_{1}$, verificando-se tambēm o papel da seleção diplôntica durante o desen volvimento dessas plantas. 


\section{REVISĀO DE LITERATURA}

Os assuntos abordados nesta revisão são apresentados em quatro tópicos: a) Generalidades sobre a indução de mutações no melhoramento de plantas, com ênfase àquelas produzidas por neutrons rápidos; b) Fertilidade das plantas $M_{1}$; c) Coloração do tegumento da semente e sua relação com a coloração do hipocótilo; d) Quimerismo em plantas.

2.1. Generalidades sobre a indução de mutações no melhoramento de plantas

Desde a descoberta dos raios-X por ROENTGEN em 1895, muitas investigações têm sido feitas para determinar seus efeitos sobre os organismos vivos. Apesar disso, somente ficou estabelecido que irradiações com raios-X podem acarretar mutações a partir dos resultados obtidos por MULLER (1927) em Drosophila melanogaster.

STADLER (1928 a, 1928 b) demonstrou em cevada e em milho o mesmo fenômeno descrito por MULLER (1927), sendo assim obtidos os prime ros resultados em cereais irradiados. Um estudo desse tipo foi feito por GENTER e BROWN em 1938 (publicado em 1941), submetendo à ação dos raios-X 
sementes de feijão, com os objetivos de determinar os tipos de mutaçoes que poderiam ser produzidas e as suas respectivas taxas.

OLIVER (1930) e DEMEREC (1933) analisaram a relação entre a frequência de mutação letal em Drosophila e a dosagem de raios-X aplicada, e concluíram que a frequência de mutação aumentava proporcionalmente ao aumento da dosagem. Resultados similares foram encontrados por TIMOFÉEFF-RESSOVSKY et alii (1935). Desde essa época, os efeitos biológicos das radiações têm sido estudados, tanto sob o ponto de vís ta básico quanto do aplicado, por grande número de pesquisadores.

Em 1942, Auerbach e Robson, como citado por AUERBACH (1949) descobriram o primeiro agente químico capaz de produzir mutações nos or ganismos. Essa substância, o gás mostarda, foi usado em Drosophila meZanogaster causando efeitos semelhantes aos dos raios-X. Com essa descoberta, uma grande quantidade de produtos químicos têm sido testados, apresentando bons resultados como agentes mutagênicos (KONZAK et alii, 1965).

Os estudos dos efeitos dos mutagênicos físicos e químicos podem ser realizados pelo tratamento de todas as partes da planta. Mas,segun do BRIGGS e KONZAK (1977) e KAMRA e BRUNNER (1977), a escolha a ser feita pelo pesquisador, concernente à parte da planta ou estágios mais apropriados à exposição aos mutagênicos, deve levar em conta os objetivos do experi mento e requer um certo conhecimento do material a ser estudado. Os autores. ressaltam ainda que as sementes parecem constituir material favorável em mui tos experimentos de indução de mutação.

A radiação-X foi a primeira das radiações ionizantes empre- 
gadas pelos geneticistas para a indução de mutações em plantas, como citado anteriormente. No entanto, com a introdução dos reatores nucleares, passou-se a utilização dos neutrons. Os neutrons, segundo BRIGGS e CONSTANTIN (1977), com uma ampla gama de energia, podem ser obtidos de um reator onde o ${ }^{235} \mathrm{U}$ é submetido à fissão nuclear. Assim, com base em seus espectros energéticos, eles são divididos em rápidos e térmicos. A maioria tem energia entre 0,5 e 2,0 MeV e são denominados de neutrons rápidos. Por reação com moderadores, tais como carbono e hidrogênio, os neutrons rápidos são reduzidos em sua energia a cerca de $0,025 \mathrm{eV}$ e recebem, nesse esta do, a denominação de neutrons térmicos.

Quando comparados com as radiações esparsamente ionizantes como os raios-X ou a radiação gama, os neutrons térmicos e rápidos são con siderados mais eficientes na indução de vários efeitos biológicos. Entretanto, não foram detectadas diferenças nos efeitos biológicos entre os dois tipos de neutrons em trabalhos realizados em cevada por CALDECOTT (1955).

Hā algumas décadas atrās, entretanto, o uso dos neutrons foi prejudicado por falta de técnicas dosimétricas adequadas, por falta de dosimetria uniforme para o uso dos vários reatores e pelos diversos pro cedimentos ao reportar a dosagem e o espectro de neutrons usados (SMITH, 1961). Assim, existe um certo grau de confusão em relação aos resultados dos primeiros experimentos realizados com neutrons.

Os neutrons têm se mostrado altamente eficientes na indução de mutações em plantas. Podemos observar pelos resultados experimentais obtidos em diversos trabalhos com neutrons rápidos, que dependendo da cultivar e da finalidade proposta, eles apresentarão uma maior ou menor 
eficiência.

Irradiando grãos de pólen de Tradescantiasppp com vārias dosa gens de neutrons rápidos, GILES (1943) observou que as frequências das aberrações cromossômicas aumentavam linearmente com as dosagens. Résultados semelhantes a estes foram obtidos por PILCH (1977) quando irradiou grãos de centeio com dosagens de neutrons rápidos variando de 410 a 2150 rad. Este autor tambēm verificou que o índice mitótico, determinado em células meristemáticas de pontas de raízes, decresceu com o aumento da dosagem de radiação aplicada.

Estudos mostraram que a sobrevivência das plântulas $M_{1}$ sofre uma redução proporcional ao aumento das dosagens de neutrons aplicadas (BIRDIE YEH e HENDERSON, 1963; MIKAELSEN et alii, 1968; PILCH, 1977).

SARAFI (1974) fez uma comparação de uma variedade controle de feijoeiro commutantes dessa variedade selecionados na geração $M_{4}$, obtidos por aplicação de neutrons rápidos e demonstrou que: (i) o número de va gens por planta em um dos mutantes foi significativamente mais elevado do que no controle; (ii) o número de sementes por vagem foi mais baixo na mai oria dos mutantes; (iii) o peso de 100 sementes foi significantemente mais alto em dois dos mutantes selecionados.

Um experimento efetuado para comparar os efeitos das radiaçôes ionizantes e mutagênicos químicos, foi feito por KULIEV (1978) em Gossypium hirsutum. 0 autor verificou que o mutagênico mais eficiente em ter mos de frequência de mutação foram os neutrons rápidos, mas em relação à percentagem de mutantes üteis, a etilenimina tomou o primeiro lugar.

Num estudo sobre o uso da irradiação com neutrons no desen- 
volvimento de novas variedades de plantas cultivadas, com particular referência ao melhoramento de lentịlha, ervilha, feijão, cevada e nabo, UHLIK (1979) apresenta dados sobre a eficácia de ambos neutrons, rápidose tér micos, em comparação com outros mutagênicos físicos e químicos. As conclu sões tiradas foram: para a lentilha, o N-nitroso-N-etiluréia mostrou-se mais eficiente do que os neutrons rápidos ou térmicos, na indução de mutan tes de clorofila na geração $\mathrm{M}_{2}$; jā para o nabo, os neutrons térmicos foram mais eficientes do que o N-nitroso-N-etiluréia.

Diversos experimentos realizados com neutrons rápidos, mostram a obtenção de mutantes úteis para diferentes características. Entre estes, salientam-se aqueles pelos quais foram selecionados mutantes para:

(i) maior teor de proteína nos grãos: VASILEVA (1975) em er vilha, NAGL (1979) em Vicia faba, SAJó (1979) e MONYO e SUGIYAMA (1979) em arroz, HADJICHRISTODOVLOV e DELLA (1979) em cevada;

(ii) maior número de sementes/planta: VASILEVA (1975)e GOTTㅗㅗ CHALK (1977) em ervilha, MONYO e SUGIYAMA (1979) e SAJō (1979) em arroz;

(iii) mais alta resistência a doenças: SAJÓ (1979) em arroz e STOILOV e POPOV (1978) em linhagens de milho;

(iv) arquitetura da planta: VASILEVA (1975) em ervilha. 


\subsection{Fertilidade de plantas $M_{1}$}

Existem diversos caracteres utilizados para a determinação da fertilidade das plantas $\mathrm{M}_{1}$ em feijão: número de ramificações/planta, nū mero de vagens/planta, número de sementes/planta, número de vagens/ramificação e número de sementes/ramificação. MOTTO et alii (1975), estudando os efeitos de diferentes dosagens de mutagênicos químicos sobre a fertilidade das plantas $M_{1}$ de feijão, verificaram que os nümeros médios de ramifí cações primárias, de vagens e de sementes por planta, decresceram com o au mento das dosagens empregadas. Os caracteres "vagens e sementes por ramificação" não foram significativamente diferentes entre os tratamentos. Con cluíram, então, pelos resultados obtidos, que a fertilidade das plantas $\mathrm{M}_{1}$ parece ser principalmente dependente do nümero de ramificações.

Estudos efetuados em arroz por BIRDIE YEH e HENDERSON (1963), MIKAELSEN et alii (1968), MIAH e AWAN (1971) e EL-KEREDY e ABD-ALLA (1976), levaram à conclusão de que com o aumento das dosagens de radiação ocorre um decréscimo da fertilidảde. Mas a relação entre o efeito e as dosagens foi mostrado ser não linear por YAMAGUCHI (1962) e variável de acordo com a vạ riedade estudada (EL-KEREDY e ABD-ALLA, 1976).

W0O et alii (1971), aplicando radiação gama em grãos de ar roz, verificaram que em dosagens relativamente baixas de 20 a $25 \mathrm{krad}$, havia uma predominância de : plantas $M_{1}$ semi-férteis, e para a dosagem de 30 krad apareciam mais semi-estēreis, sendo que para 40 e $50 \mathrm{krad}$, a maioria das plantas era altamente estéril. Os autores concluíram, portanto, que a fertilidade apresenta-se em diversas gradações que variam proporcionalmente às dosagens empregadas. 
Muitos pesquisadores acham que a esterilidade resultante da irradiação pode ser atribuída a anormalidades cromossômicas. Em plantas de arroz, Nagamatsu (1950) e Nishimura (1950), citados por MATSUO et alii (1958), reportaram que a maior parte das plantas estéreis produzidas após a explosão da bomba atômica mostraram várias trocas cromossômicas em sua meiose, e além disso, a esterilidade parcial, seguindo-se a irradiação-X e ra, principalmente, devida a translocações recíprocas dos cromossomos. Con cordantemente, MATSUO et alii (1958) supuseram que a esterilidade induzida pela irradiação é fundamentalmente devida a aberrações cromossômicas e a $\underline{e}$ levação do número de panículas completamente estéreis, conforme o aumento das dosagens, deve estar relacionada a uma substituição de um tipo de aberrações cromossômicas por outro mais complicado. YESODA RAJ et alii (1972) também verificaram que o aumento nas dosagens de irradiação resultou em uma maior porcentagem de aberrações cromossômicas. .

\subsection{Coloração do tegumento e sua relação com a coloração do hipocōtilo}

Os genes que determinam a coloração dos tegumentos seminais do feijão comum têm sido muito estudados por diversos autores, entre os quais LAMPRECHT (1935 a, 1947), SMITH (1939) e PRAKKEN (1942, 1959, 1970). Alguns autores como SHAW e NORTON (1918), KOOIMAN (1931), SMITH (1939), FEENSTRA (1960) e YARNELL (1965), desenvolveram esquemas genéticos que explicam a transmissão da coloração.

Segundo VIEIRA (1967) a coloração do hipocótilo do feijoe ro pode ser classificada em três tipos: vermelho, rosa e verde. Todavia, este é um carāter geneticamente muito complexo, pois envolve uma série de 
alelos mü1tiplos que governam a coloração do hipocótilo e ao mesmo tempo das flores (LAMPRECHT, 1935 b), e tambēm fatores inibidores que têm a capacidade de atuar sobre alguns desses alelos impedindo a sua ação (NAKAYAMA, 1958, 1959, 1965).

Alguns trabalhos efetuados e que são reportados a seguir, $\underline{e}$ videnciam muito bem a relação existente entre a coloração do tegumento e a do hipocótilo.

$\mathrm{MOH}$ (1971), tratando três variedades de feijão preto com di ferentes dosagens de EMS e radiação gama, obteve mutantes para a coloração da semente variando do branco, amarelo a diversos graus de marron. Todos esses mutantes estavam associados com uma mudança na coloração do hipo cótilo de vermelho para verde, possibilitando assim, sua detecção num estáa gio muito precoce do desenvolvimento da plântula. A maioria dos mutantes selecionados para coloração da semente apresentaram a mesma morfologia geral e. hábito de crescimento que os seus parentais originais, mas diferiam tambēm por produzirem sementes menores e em quantidade mais abundante.

CHOMŌN (1972) fazendo uso da correlação existente entre a coloração do hipocótilo e a do tegumento, jā verificada por $\mathrm{MOH}$ e ALAN em 1971, e empregando EMS em diferentes cultivares de feijoeiro com tegumento preto e hipocótilo vermelho e em outras com tegumento e hipocótilo vermelhos, conseguiu induzir mutação no hipocótilo de coloração vermelha para verde. Assim, selecionou os mutantes no estágio de plântulas $M_{2}$ e verificou a existência de mutações para coloração da semente em quatro das seis cultivares estudadas. As mutações obtidas para coloração da semente foram: branca, amarela-pālida, marron, marron amarelado e preto com manchas brancas. Concluiu que estas são de carāter recessivo e monogênicos, transmiti 
dos em forma mendeliana simples. Os mutantes para coloração da semente sao devidos à mutação do gene $P$ que determina a presença ou ausência da colora ção do tegumento.

\subsection{Quimerismo em plantas}

A existência de quimeras em plantas é conhecida há vārias centenas de anos. TANAKA (1927) citou a laranja Biazzaria, observada em 1644, como sendo o primeiro exemplo. Essa quimera sintética consiste de Citrus aurantium L. e Citrusmedica L. Entretanto, foi WINKLER (1907), citado por FARESTVEIT em 1968, quem primeiramente usou o termo quimera para descrever uma planta composta de tecidos genotipicamente diferentes. WINKLER empregou o termo para: designar plantas que consistem de tecidos de duas espécies diferentes de plantas, enquanto BAUR (1908, 1909), segundo FAREST VEIT (1968), extendeu este termo incluindo plantas compostas de tecidos genotipicamente diferentes derivádos de uma mesma espécie de planta. Ao mesmo tempo, essa terminologia foi especificada de modo que as quimeras de WINKLER compreendiam aquelas normalmente instáveis, enquanto as quimeras de BAUR compreendiam as periclinais que ocorrem mais frequentemente e são os únicos tipos estāveis.

Após a descoberta do efeito mutagênico da radiação-X por MULLER, em 1927, o uso generalizado de sementes para a indução de mutação levou a um aumento no interesse do conhecimento sobre a estrutura quimérica das plantas $M_{1}$ provenientes de sementes tratadas. São denominadas sementes $M_{1}$ aquelas que receberam os tratamentos com mutagênicos físicos e/ou químicos. 
tações induzidas por irradiação de grãos apareciam como setores nas plan tas $M_{1}$. Demonstrou também que em cevada, as células iniciais presentes no embrião das sementes jā estão diferenciadas, de modo que a ocorrência de u ma mutação afeta somente uma espiga. Desde este tempo têm havido diversas tentativas no sentido de determinar o número de células iniciais presentes no embrião, em muitas espécies de plantas cultivadas.

Os estudos de GUSTAFSSON (1940), FREISLEBEN e LEIN (1943) e KAPLAN (1949, 1951), segundo D'AMATO (1965), sobre a relação dé frequência de mutação em clorofila e a dose de radiação em cevada, acentuaram a importância da competição celular durante o desenvolvimento de uma planta $\mathrm{M}_{1}$, de semente irradiada.

ANDERSON et alii (1949) foram os primeiros a mostrar que a anālise de setores mutados pode auxiliar em grande parte o estudo da ontogenia de órgãos em plantas. Relataram também que um pendão de milho tem origem a partir de 7 a 8 células jā presentes no ápice da semente dormente.

CALDECOTT e SMITH (1952) e KAUKIS e REITZ (1955) investigando a distribuição de aberrações cromossômicas e de plântulas mutantes induzidas por raios-X em cevada e sorgo, respectivamente, apresentaram dados sobre o nūmero de células embrionārias responsāveis pela organização do tecido generativo de uma espiga e panícula nestas espécies. Os primeiros concluíram que uma espiga de cevada desenvolve-se de uma única célula inicial, enquanto que, para o sorgo, KAUKIS e REITZ (1955) verificaram existir mais de uma célula inicial no embrião da semente.

BLIXT et alii (1958) observaram que em Pisum só ocorria mutação em uma ramificação e, portanto, concluíram que uma ramificação de 
senvolve-se de uma única célula inicial.

Em café foi verificado por MOH (1961) que, exceto para a epiderme, o desenvolvimento de um caule jovem ocorre através de uma única célula inicial. o autor baseou sua conclusão na alta frequência de mutantes não-quiméricos em $R_{1}$, nas formas das curvas de resposta à dosagem de raios-X e neutrons e na associação da esterilidade do pólen com alguns mutantes.

ANDO (1970), utilizando radiação gama e EMS, mostrou que na cultivar de arroz Dourado Precoce, as ramificações primārias originam-se de uma única célula inicial. Verificou também que as panículas que flores ciam primeiro foram provenientes de um maior número de células iniciais do que as que floresciam mais tardiamente. Além disso, através desse experimento, ficou demonstrado que o número máximo de células iniciais foi de seis e que este sofreu um decréscimo conforme o aumento da dosagem ou da concentração dos mutagênicos aplicados, sendo que esta última conclusão foi corroborada mais recentemente (1975) por MOTTO et alii, em feijão.

Em Phaseolus vulgaris L. MOTTO et alii (1975) determinaram as frequências de mutações por plantạ levando em consideração as gerações $M_{2}$ e $\mathrm{M}_{4}$. Trataram sementes dormentes com diferentes concentrações de solução de EMS e, com base nas taxas de segregação obtidas, verificaram que o nūme ro de células iniciais presentes no meristema apical do embrião, variou de três a oito para a planta toda e de um a três para as ramificações primárias. Os resultados experimentais indicaram uma origem pós-tratamento das iniciais da ramificação primária. Não foram encontradas evidências da ocorrência de seleção diplôntica durante a ontogenia de uma planta mutante na variedade estudada Royal Red. 
Foram verificadas por alguns autores, diferenças quanto aos efeitos de mutagênicos químicos e físicos sobre as taxas de segregação observadas. Um dos trabalhos que demonstraram este fato foi realizado por YAMAGUCHI e MIAH (1964) que compararam os efeitos de radiações ionizantes (raios-X e gama) e etilenimina em doses relativamente baixas sobre grãos da cultivar Kinmaze de arroz. Observaram a existência de uma relação linear entre a frequência de mutação e a dose de raios-X e radiação gama e também que não havia diferença significativa na produção de mutações pelos dois tipos de radiação. Para os materiais irradiados com dose suficientemente baixa e tratados com etilenimina, as taxas de segrega ção dos mutantes em clorofila nas ramificações $\mathrm{x}_{1}$ mostraram um grande défi cit em recessivos. Com doses mais altas, entretanto, as taxas de segregação aproximaram-se da esperada de $25 \%$.

Geralmente são utilizados três métodos para estimar as fre quências de mutações em clorofila, induzidas por mutagênicos: determinação em plantas $M_{1}$, espigas $M_{1}$ e plântulas $M_{2}$. GAUL $(1960,1961)$, segundo MOHAN RAO (1972), trabalhando com cevada, considerou o método de plântulas $M_{2}$ superior aos outros dois métodos. Através de considerações teóricas e dados experimentais, concluiu que os métodos de anālise de mutação em plantas $M_{1}$ e espigas $M_{1}$, geralmente subestimam a verdadeira frequência de muta ção, e sugeriu que isto seja causado pela variação do tamanho do setor mutante e esterilidade. Os resultados e cálculos de GAUL indicaram que o mé todo de anālise em plântulas $\mathrm{M}_{2} \overline{\mathrm{e}}$ menos influenciado pela variação em tama nho dos setores mutantes e esterilidade induzida nas espigas. Em contraste, ARNASON et alii (1962), conforme MOHAN RAO (1972), acharam que a me 1hor medida de mutações transmitidas é obtida pelo método de espigas $M_{1}$. Os autores sugeriram que o método de plântulas $M_{2}$ não fornece resultados 
adequados porque o nūmero total de plântulas mutantes detectadas está relacionado com o tamanho médio do, setor mutante nas espigas mutadas, bem como o número de mutações esperadas. Após a comparação dos vārios métodos de anālise de mutação, SARVELLA et alii (1962) concluíram que taxas de mutação dignas de confiança, podem ser obtidas pelo método de espigas $M_{1}$. Mais recentemente, outros autores como MOHAN RAO (1972), obtiveram resultados que concordam com os de GAUL (1960). $\quad 0$ autor realizou estudos sobre os três métodos de medida de frequência de mutação em cevada, usando combi nações de tratamentos com raios-X ou gama e DES. Conside rou o método de plântulas $M_{2}$ superior aos outros dois métodos. Concluiu que os métodos de análise de plantas $M_{1}$ e espigas $M_{1}$ são incapazes de registrar a frequência de células iniciais mutantes em cada primórdio de espiga, que juntamente com a frequência de espiga primordial mutada, determi na a frequência total de mutação induzida.

Hā autores que sugerem que a determinação de mutantes em pesquisa sobre a formação de quimera oferece resultados mais precisos quan do realizada na geração $M_{3}$ e que é mais vantajosa, principalmente quando o setor mutado na geração $M_{1}$ é de pequeno tamanho. Em cevada, GUSTAFSSON e MOES (1959), citados por MOTTO et alii (1975), verificaram que algumas mutações que segregaram na geração $M_{3}$ não haviam sido detectadas em $M_{2}$. YAMAGUCHI (1962) realizou uma pesquisa sobre a formação de quimera em panícula $\mathrm{x}_{1}$ apōs a irradiação de sementes dormentes de arroz e determinou a proporção de mutantes nas gerações $\mathrm{x}_{2}$ e $\mathrm{x}_{3}$. Verificou que a taxa de segregação nas progênies $\mathrm{x}_{2}$ foi significativamente menor que o esperado de $25 \%$, mas que as taxas nas progênies $x_{3}$ aproximavam-se bastante da normal. 


\section{MATERIAL E METODOS}

\subsection{Material}

0 material usado para a realização do presente trabalho foi sementes de feijoeiro (Phaseolus vulgaris L.), da cultivar Costa Rica, fornecidas pelo Setor de Radiogenética do Centro de Energia Nuclear na Agricultura (CENA/USP). Essas sementes foram provenientes de ensaios de seleção efetuados pelo referido setor, junto à Estação Experimental de Tietê, do Instituto Agronômico de Campinas, SP. Tais ensaios foram levados a efeito com o objetivo específico de obter-se material com características bastante uniformes, tornando-se assim, ideal para ser empregado em experimentos de mutações induzidas, nos quais a uniformidade do material é altamente recomendāvel.

Como agente mutagênico foi utilizada a irradiação com neutrons rápidos, realizada no reator nuclear do Laboratōrio de Seibersdorf, da Agência Internacional de Energia Atômica (IAEA), Viéna, Āustria.

Algumas características gerais do material estudado, segundo TULMANN NETO (comunicação pessoal), são apresentadas a seguir: - 


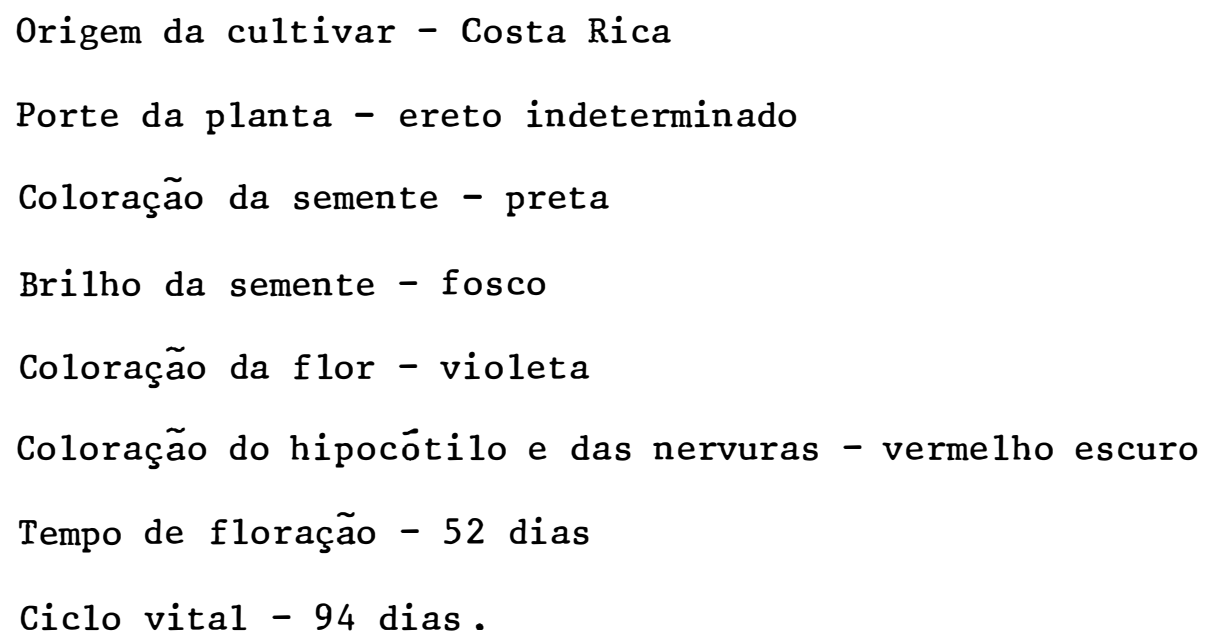

\subsection{Métodos}

\subsubsection{Tratamentos mutagênicos}

Sementes do material que serviu de base para o presente estudo foram irradiadas no reator do tipo "piscina" do Laboratōrio de Seibersdorf. Para esse tratamento o material foi colocado em saquinhos plás ticos, e irradiado pelo método de "mergulho", dentro da "piscina".

A intensidade de radiação usada foi de $0,278 \mathrm{krad} / \mathrm{min}$, a uma potência de 7,5 MW.

Os tratamentos mutagênicos foram realizados atravēs da aplị cação de neutrons rápidos nas seguintes dosagens: 0, 0,5 e 1,0 krad em 400 sementes; $1,5,2,0$ e $3,0 \mathrm{krad}$ em 500 sementes e $2,5 \mathrm{krad}$ em 550 semen tes. Logo depois de irradiado, o material foi enviado ao Brasil. 


\subsubsection{Execução experimental}

0 material tratado com neutrons rápidos foi recebido de vie na em 24/02/77 e o ensaio foi instalado em campo experimental do Departamento de Genética da Escola Superior de Agricultura "Luiz de Queiroz", USP, em Piracicaba, em 22/04/77.

As sementes $M_{1}$ dos 7 tratamentos foram semeadas em um espaçamento de $40 \mathrm{~cm}$ entre fileiras e $20 \mathrm{~cm}$ entre covas.

Em julho de 1977 , as sementes $M_{2}$ produzidas pelas plantas $M_{1}$ sobreviventes foram colhidas vagem por vagem, ramificação por ramificação, planta por planta, separadamente em cada tratamento.

Para a obtenção da geração $M_{2}$ foram usadas as plantas $M_{1}$ que possuiam número razoável de sementes. Assim, foram tomadas sementes $\mathrm{M}_{2}$ de 10 plantas $M_{1}$; correspondentes a cada uma dos tratamentos de 0 e 1,5 krad e de 15 plantas $M_{1}$, correspondentes aos tratamentos de 0,5, 1,0 e 2,0 krad. As dosagens de 2,5 e 3,0 krad foram letais. A semeadura foi feita em campo experimental do Departamento de Genética da ESALQ/USP, em fevereiro de 1979. As sementes $M_{2}$ foram semeadas em fileiras, com um espaçamento de 40 $\mathrm{cm}$ entre fileiras e $20 \mathrm{~cm}$ entre covas. Neste processo tomou-se o cuidado para identificar-se, posteriormente, as vagens pertencentes a uma determinada ramificação e a uma determinada planta. Desse modo, as sementes foram semeadas em progênies de cada vagem, de cada ramificação, pertencentes a uma certa planta, dentro de cada um dos tratamentos.

Aproximadamente 20 dias após a semeadura foram feitas as contagens dos números de sementes germinadas. Em maio, alguns dias antes da colheita, foram contados os nümeros de plantas $\mathrm{M}_{2}$ sobreviventes. 
As plantas $\mathrm{M}_{2}$ foram colhidas, separadamente, planta por plan ta, para cada um dos tratamentos.

As observações dos diferentes tipos de mutações originadas, e as determinações das respectivas frequências foram efetuadas em plântü las da geração $M_{3}$. Para a coleta desses dados, as sementes $M_{3}$ de cada plan ta $M_{2}$ foram misturadas, tomando-se o cuidado de semear-se, como na geração $\mathrm{M}_{2}$, separadamente, sementes provenientes de cada vagem, de cada ramificação, dentro de uma determinada planta $M_{1}$. Devido ao enorme volume de mate rial a ser manipulado, nesta etapa do experimento, foram desprezados os tra tamentos com 0,5 e $1,5 \mathrm{krad}$, utilizando-se assim, somente sementes $\mathrm{M}_{3} \mathrm{o}^{-}$ riundas dos tratamentos $\operatorname{com} 0,1,0$ e 2,0 krad, empregando-se para essa $\mathrm{f}_{\underline{\mathbf{i}}}$ nalidade, respectivamente, progênies de 4,11 e 11 plantas $M_{1}$. Tais sementes $M_{3}$ foram semeadas em canteiros de areia, em casa de vegetação do De partamento de Genética, em um espaçamento de $5 \mathrm{~cm}$ entre fileiras e $5 \mathrm{~cm}$ entre covas (Figura 13).

Aos 7 e 9 dias após a semeadura foram feitas, respectivamente, as contagens dos números de sementes germinadas e o registro das plântulas mutantes.

Os valores das frequências de mutações foram obtidos pelo quociente entre o número de plântulas mutantes e o número total de plântụ las $\mathrm{M}_{3}$ observadas.

\subsubsection{Classificação das mutações}

Foram consideradas 5 classes de mutações: hipocótilo verde, hipocótilo rosa, clorofílicas letais, clorofílicas não-letais e morfoló- 
gicas.

As mutações clorofílicas letais abrangeram os tipos albina (planta branca), xanta(planta amarela) e rosa-verde. As clorofílicas não-letais incluíram todos os demais tipos de mutações em clorofila registrados, e que também estão compreendidos na classificação de HOLM (1954), feita em cevada:

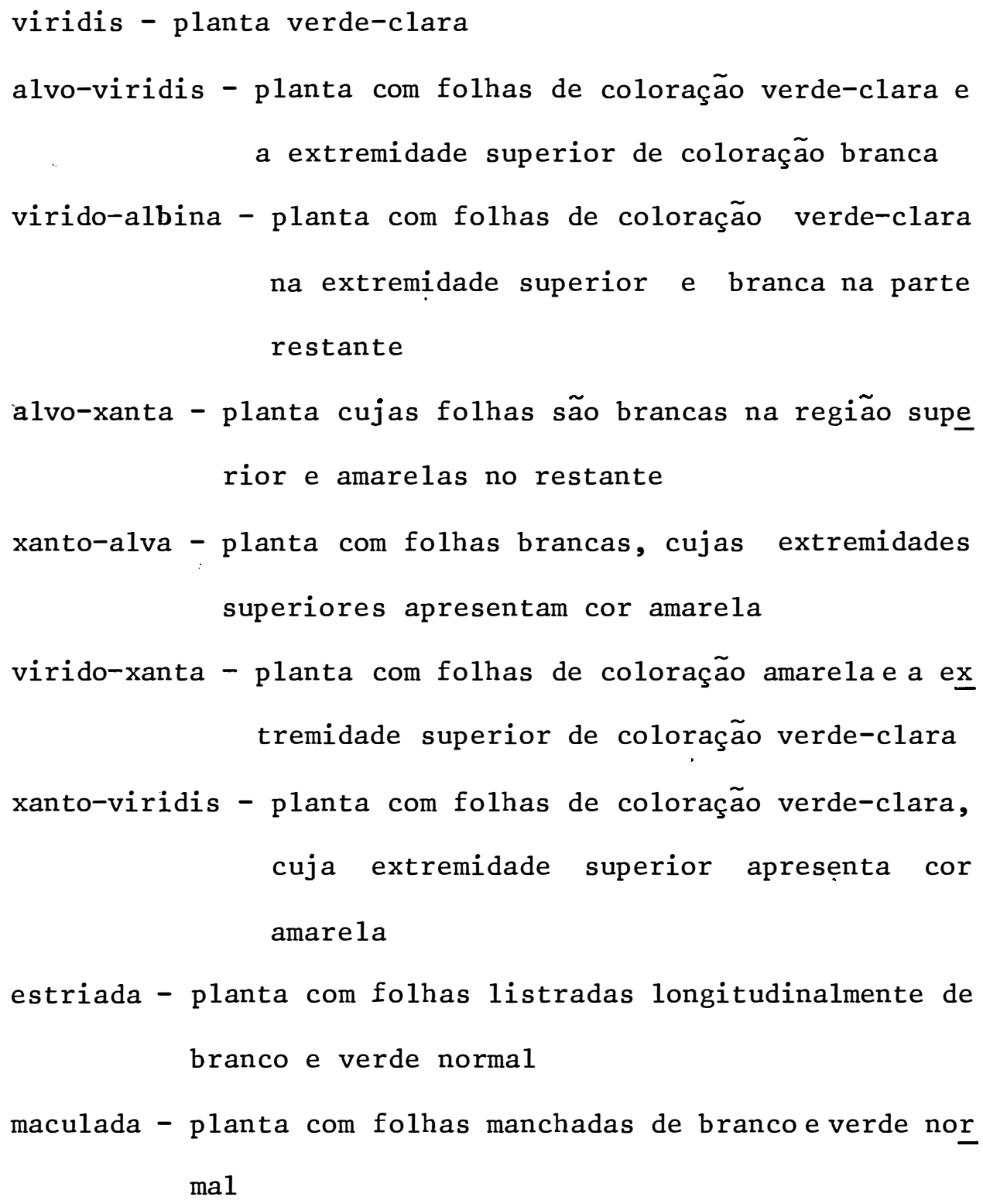




\subsubsection{Fertilidade das plantas $M_{1}$}

Com a finalidade de verificar-se os efeitos das diferentes dosagens de neutrons rápidos sobre a fertilidade das plantas $M_{1}$, foram estudados os caracteres relacionados à fertilidade, tais como: número de ramificações primárias, número de vagens e número de sementes produzidas por planta. Para isto, protocolou-se o número de sementes de cada vagem dentro de uma determinada ramificação, dentro de uma determinada plantae den tro de uma determinada dosagem.

\subsubsection{Taxa de segregação}

As taxas de segregação obtidas após um tratamento mutagênico podem ser usadas para elucidar a natureza da condição quimérica das plan tas tratadas. Para essa anālise foram usados os diferentes tipos de muta ções observadas na geração $M_{3}$. As determinações foram efetuadas de diversas maneiras, conforme discriminação a seguir:

(i) em cada tratamento, para todos os tipos de mutações observadas;

(ii) para as mutações agrupadas em cinco categorias: hipocōtilo verde, hipocótilo rosa, clorofílicas letais, cloro fílicas não-letais e morfológicas, para cada tratamento;

(iii) dentro de cada tratamento, conservando-se as categorias de mutações relacionadas no item (ii), mas considerando as plantas divididas em 4 grupos, conforme o número de ramificações primārias presentes em:plantas com uma, com 2, com 3 e com mais do que 3 ramificações primárias; 
(iv) para mutações agrupadas em: hipocótilo verde, hipocótilo rosa, clorofílicas e morfológicas, em plantas class $\underline{i}$ ficadas conforme o número de ramificações primárias, co mo citado no item (iii).

3.2.6. Nūmero de cēlulas iniciais presentes no embrião das sementes e estrutura quimérica das plantas $M_{1}$

A determinação do número de células iniciais do embrião foi efetuada para cada planta de cada um dos tratamentos com 1,0 e 2,0 krad, para em seguida calcular-se o número médio de células iniciais por tratamento e para cada um dos tipos de mutações consideradas. Para isso, foram catalogados os mutantes das progênies $\mathrm{M}_{3}$ provenientes de cada uma das plantas $M_{1}$, separadamente. 0 modo como foram conduzidos os ensaios, descritos no item 3.2.2., tanto no campo, por ocasião do plantio da geração $M_{2}$, quan to na casa de vegetaçãc quando da semeadura das sementes da geração $\mathrm{M}_{3}$, permitiu que cada mutante observado pudesse ser identificado de maneira a se saber de qual vagem e de qual ramificação da planta $M_{1}$ foi originário. Isso também permitiu a elaboração de uma análise topográfica de cada uma das plantas $M_{1}$ com a finalidade de estudar-se a estrutura quimérica destas.

Considerando-se que se uma única célula inicial for envolvi da na formação da inflorescência da planta $M_{1}$, e esta sofrer uma mutação recessiva, as sementes $\mathrm{M}_{2}$ que se originarão terão os genótipos $A A$, Aa e aa, na proporção de $1: 2$ : 1, para o loco em questão. Assim 50\% das sementes $M_{2}$ de cada planta $M_{1}$ irão segregar na geração $M_{3}$ em proporção de 1:2:1, permitindo a observação dos mutantes recessivos. Para o caso das mutações letais, que apareceriam na geração $M_{2}$ em proporção de $25 \%$ seriam elimina- 
das, sendo que somente plantas homozigotas AA, ou heterozigotas Aa para o referido 1oco, chegariam a produzir sementes $M_{3}$. Seguindo-se esse raciocínio, os números de células iniciais foram determinados empregando-se as seguintes expressões:

$$
x=\frac{z}{y} \text { sendo } y=\frac{a}{b}
$$

onde: $\mathbf{z}=$ proporção esperada de heterozigotos, apresentando valores iguais a 0,5 (mutações não-letais) e a 0,67 (mutações letais) na geração $\mathrm{M}_{2}$;

$y=$ proporção observada de heterozigotos :na geração $\mathrm{M}_{2}$;

$\mathrm{a}=$ nümero de sementes $\mathrm{M}_{2}$ heterozigotas;

$\mathrm{b}=$ número total de sementes $\mathrm{M}_{2}$ produzidas pela planta $\mathrm{M}_{1}$ $\mathrm{x}=$ número de células iniciais.

\subsubsection{Anālises estatísticas}

\subsubsection{Fertilidade das plantas $M_{1}$}

Foram determinadas as mēdias dos nümeros de: ramificações, vagens e sementes por planta dentro de cada dosagem. A partir destes dados foram efetuadas as relações de: ramificação/planta, vagem/planta, semente/planta, vagem/ramificação, semente/ramificação, dentro de cada trata mento, e os respectivos desvios padrão.

A anālise da variância foi feita seguindo-se a Classificação Hierārquica com números desiguais nas sub-classes, e os valores das espe ranças do Quadrado Médio foram estimados segundo ANDERSON e BANCROFT (1952), conforme o esquema: 


\begin{tabular}{lr} 
Fonte de Variação & G.L. \\
\hline Dosagem (D) & 2 \\
Planta (P) /D & 23 \\
Ramificação (R)/P/D & 204 \\
Vagem/R/P/D & 414 \\
\hline
\end{tabular}

Total

Os valores relativos aos números de sementes foram transfor mados em $\sqrt{x+1 / 2}$, segundo recomendação de STEEL e TORRIE (1960).

\subsubsection{Germinação e sobrevivência na geração $M_{2}$}

Os números de sementes $\mathrm{M}_{2}$ germinadas e de plantas $\mathrm{M}_{2}$ sobreviventes, dentro de cada tratamento, foram analisados, estatisticamente,pe la determinação dos valores de $\chi^{2}$, aplicando-se o teste de contingência. Este teste foi efetuado para os seguintes casos:

(i) entre as 5 dosagens conjuntamente;

(ii) entre a testemunha ( $0 \mathrm{krad})$ e as demais dosagens;

(iii) entre as dosagens de $0,5,1,0,1,5$ e 2,0 krad, combina das 2 a 2 .

\subsubsection{Germinação na geração $M_{3}$}

Para analisar-se a germinação das sementes $M_{3}$ foram também empregados os valores do $\chi^{2}$ obtidos pelo teste de contingência realizado entre:

(i) as 3 dosagens usadas; 
(ii) a testemunha e as demais dosagens;

(iii) as dosagens de 1,0 e $2,0 \mathrm{krad}$.

\subsubsection{Frequências de mutaçōes em plântulas $M_{3}$}

Os efeitos dos neutrons rápidos sobre as frequências de mutações foram verificadas, estatisticamente, pela determinação dos valores do $\chi^{2}$ aplicando-se o teste de contingência. Este foi efetuado com os valores observados de plântulas mutantes e não-mutantes, para os mesmos casos citados no item 3.2.7.3. Para a anālise foram considerados todos os ti pos de mutações em conjunto, isto é, mutações de clorofila, para coloração do hipocótilo e morfológicas. 


\section{RESULTADOS E DISCUSSÃO}

\subsection{Fertilidade das plantas $M_{1}$}

Os danos fisiológicos observados na geração $M_{1}$ podem ser me. didos quantitativamente de várias maneiras, sendo que uma delas é através da determinação da fertilidade das plantas $M_{1}$.

MÜLLER (1966) em seus estudos realizados em Arabidopsis thalia na após tratamentos com EMS, concluiu que a obtenção do aumento das frequências de mutações é limitada pelo aumento da esterilidade das plantas $\mathrm{M}_{1}$ e não pelo aumento da letalidade na geração $M_{1}$. E, para os propósitos do me lhoramento de plantas é, geralmente, desejāvel aqueles tratamentos mutagêniços que propiciem baixa esterilidade e altas frequências de mutações gênicas. Portanto, a fertilidade é um parâmetro importante a ser analisado pois pode representar um limite prático para o aumento da dosagem utili zada.

Na Tabela 1 são apresentadas as estimativas da média e o respectivo desvio padrão dos caracteres relacionados à fertilidade da planta: ramificações/planta, vagens/planta, sementes/planta, vagens / ramifica- 
ção, sementes/ramificação, nos tratamentos com diferentes dosagens de neutrons rápidos. Os resultados obtidos mostraram que para a dosagem de 1,0 krad os valores para todos os caracteres estudados, foram superiores àqueles da dosagem de $2,0 \mathrm{krad}$, havendo assim, uma redução da fertilidade com o aumento da dosagem aplicada às sementes $\mathrm{M}_{1}$. Esses resultados concordam com os obtidos por MOTTO et alii (1975), que tratando sementes de feijão da cultivar Royal Red, com doses crescentes de EMS obtiveram uma diminuição nos valores desses mesmos caracteres. Para os referidos autores, a fer tilidade depende principalmente, do número de ramificações, no entanto, os caracteres que se mostraram mais influenciados pela radiação no presente trabalho foram vagens/planta e sementes/planta. Em contraposição ao verificado por MOTTO et alii (1975), a testemunha apresentou valores inferiores aos dos tratamentos com neutrons rápidos. Provavelmente, isso possa ser explicado pelo pequeno' número de plantas (em número de 4) usadas como controle, não se constituindo em uma amostra significativa, em relação ao nümero de plantas empregado nos tratamentos com neutrons rápidos, que foi de 11 , para ambas dosagens $(1,0$ e 2,0 krad).

Com os dados relativos aos números de sementes, de vagens e ramificações por tratamento, foi realizada uma análise da variância, cujos resultados são apresentados na Tabela 2. A anālise da variância mostra, a través do Teste $\mathrm{F}$, ao nível de $1 \%$ de probabilidade, que houve diferenças significativas entre dosagens, entre plantas dentro de dosagens e entre ra mificações dentro de plantas, dentro de dosagens. 0 fato do F ser signifi cativo para dosagens indica que as diversas dosagens afetaram diferentemen te o comportamento das plantas em relação ao número de sementes produzidas. Da mesma forma, o comportamento das ramificações foi diferente dentro das plantas para cada dosagem testada. 


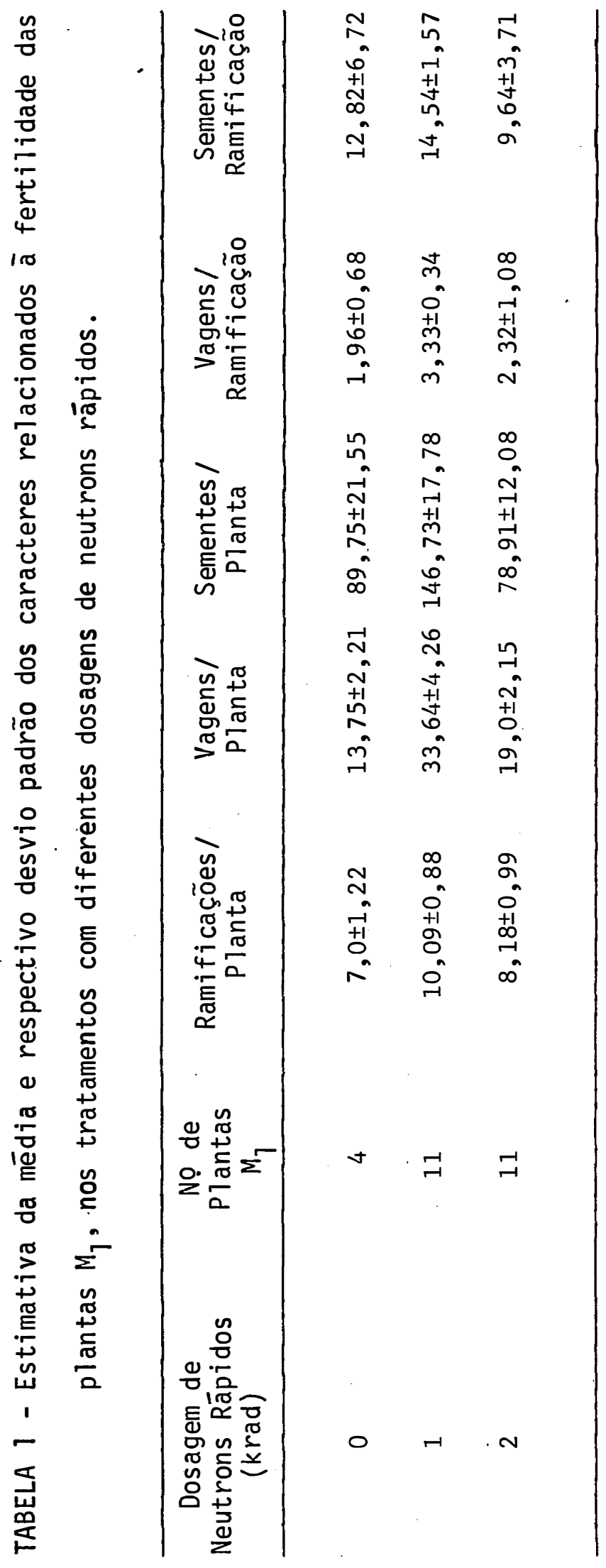


TABELA 2 - Anālise da variância: efeitos dos neutrons rāpidos sobre a fertilidade das plantas $M_{1}$. Dados transformados em $\sqrt{x+1 / 2}$.

\begin{tabular}{lrrr}
\hline Fonte de Variação & G.L. & Q.M. & $F$ \\
\hline Dosagem (D) & 2 & 6,3449 & $19,3324 * *$ \\
Planta (P)/D & 23 & 2,7631 & $11,1542 * *$ \\
Ramificação (R)/P/D & 204 & 0,4327 & $2,0314 * *$ \\
Vagem/R/P/D & 414 & 0,2190 & \\
\hline
\end{tabular}

Total

643

**: significativo ao nível de $1 \%$ de probabilidade.

\subsection{Germinação das sementes e sobrevivenncia das plantas na geração $M_{2}$}

A Tabela 3 apresenta a percentagem média de germinação das sementes e sobrevivência das plantas na geração $M_{2}$, para as 5 dosagens de radiação empregadas, assim como os valores determinados em relação à teste munha considerada como $100 \%$

Os valores percentuais de germinação das sementes e sobrevi vência das plantas na geração $\mathrm{M}_{2}$, foram relacionados com as dosagens de ne u trons rápidos recebidas pelas sementes $M_{1}$, em grä́ficos que são mostrados na Figura 1.

Os resultados mostram (Tabela 3 e Figura 1), que com o aumento gradativo das dosagens de neutrons rápidos aplicadas às sementes, 
não houve um decréscimo proporcional nas percentagens de germinação das se mentes e sobrevivência das plantas da geração $M_{2}$. Isso está de acordo com o esperado pois a germinação e a sobrevivência são parâmetros que podem ser empregados para determinar a radiossensitividade das plantas na geração $\mathrm{M}_{1}$, conforme mostram os resultados obtidos por diversos autores, entre os quais GENTER e BROWN (1941), GAUL (1960), YAMAGUCHI (1962), MIKAELSEN et alii (1968), ANDO (1970), BANDEL (1970) e STEAGALL (1977). Assim, na geração $M_{1}$ a literatura mostra que ocorre um decréscimo em germinação e sobrevivência com o aumento da dosagem de radiação empregada como um resultado de efeitos fisiológicos causados pelas radiações, e nas gerações subsequentes são detectados apenas os efeitos genéticos provocados pelas radiações.

TABELA 3 - Percentagem mēdia de germinação das sementes e sobrevivência das plantas na geração $M_{2}$, nos tratamentos com diferentes dosagens de neutrons rāpidos*

\begin{tabular}{cccc}
\hline $\begin{array}{c}\text { Dosagem de } \\
\text { Neutrons } \\
\text { Rāpidos } \\
(\text { krad })\end{array}$ & $\begin{array}{c}\text { Nọ } \\
\text { de } \\
\text { Sementes } \\
\text { Semeadas }\end{array}$ & $\begin{array}{c}\text { Germinação } \\
(\%)\end{array}$ & $\begin{array}{c}\text { Sobrevivēncia } \\
(\%)\end{array}$ \\
\hline 0 & 1145 & $42,71(100,00)$ & $32,92(100,00)$ \\
0,5 & 1736 & $36,18(84,71)$ & $26,78(81,35)$ \\
1,0 & 2386 & $48,51(113,58)$ & $38,06(115,61)$ \\
1,5 & 311 & $9,65(22,59)$ & $7,72(23,46)$ \\
2,0 & 1055 & $20,38(47,72)$ & $15,16(46,05)$
\end{tabular}

*: entre parênteses são apresentados os valores em relação à testemunha considerada como $100 \%$. 
$-31-$

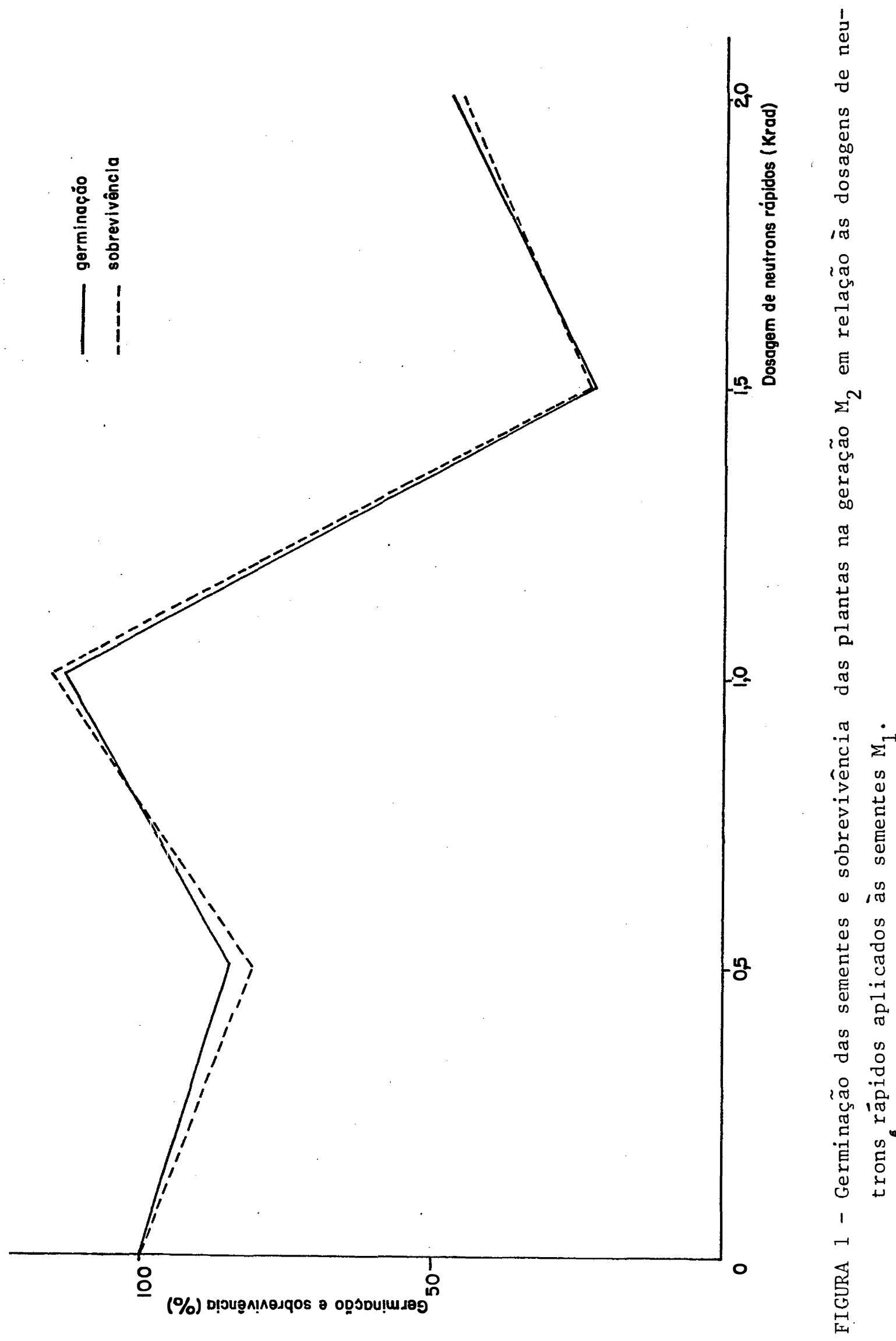


0 teste de contingência entre sementes germinadas e não ger minadas, com todas as dosagens consideradas, mostrou um valor de $\chi^{2}$ altamente significativo. Desse modo, procedeu-se a aplicação do referido teste, tomando-se a testemunha em relação às demais dosagens e também as ou tras dosagens consideradas 2 a. 2. Os valores de $\chi^{2}$ obtidos, que são signi ficativos ao nível de $1 \%$ de probabilidade, constam da Tabela 4 . 0 mesmo procedimento foi efetuado para plantas sobreviventes e não sobreviventes, sendo que os valores de $\chi^{2}$ obtidos são mostrados na Tabela 5 .

Os valores apresentados nas Tabelas 4 e 5 mostram que tanto para a germinação das sementes $M_{2}$ como para a sobrevivência das plantas $M_{2}$ houve diferenças significativas entre os valores da testemunha e os das de mais dosagens; pode-se ṫambēm observar, quando se comparou os efeitos das diversas dosagens aplicadas às sementes $M_{1}$, que estas provocaram diferentes respostas, tanto na germinação como na sobrevivência da geração $M_{2}$.

TABELA 4 - Valores de $x^{2}$ obtidos pelo teste de contingéncia entre todos os tratamentos tomados 2 a 2 , para a germinação das sementes $M_{2}$.

Dosagem de Neutrons Rāpidos (krad)

$\begin{array}{llll}0,5 & 1,0 & 1,5 & 2,0\end{array}$

\begin{tabular}{ccccc}
0 & $12,40 * *$ & $10,46 * *$ & $116,54 * *$ & $125,80 * *$ \\
0,5 & - & $62,24 * *$ & $85,10 * *$ & $77,68 * *$ \\
1,0 & - & - & $168,60 * *$ & $241,36 * *$ \\
1,5 & - & - & - & $18,80 * *$ \\
\hline
\end{tabular}

**: significativo ao nível de $1 \%$ de probabilidade. 
TABELA 5 - Valores de $\boldsymbol{x}^{2}$ obtidos pelo teste de contingēncia efetuado entre todos os tratamentos tomados 2 a 2, para a sobrevivência das plantas $M_{2}$.

\begin{tabular}{ccccc}
\hline $\begin{array}{c}\text { Dosagem de } \\
\begin{array}{c}\text { Neutrons Rápidos } \\
(\text { krad })\end{array}\end{array}$ & 0,5 & 1,0 & 1,5 & 2,0 \\
\hline 0 & $12,58 * *$ & $8,81 * *$ & $77,87 * *$ & $93,87 * *$ \\
0,5 & - & $57,48 * *$ & $52,74 * *$ & $50,98 * *$ \\
1,0 & - & - & $112,01 * *$ & $179,09 * *$ \\
1,5 & - & - & - & $11,43 * *$ \\
\hline
\end{tabular}

**: significativo ao nível de $1 \%$ de probabilidade.

Assim, houve um comportamento semelhante entre a germina ção das sementes $M_{2}$ e a sobrevivência das plantas $M_{2}$, contrariando as conclusões de YAMAGATA e SYAKUDO (1960) que não encontraram correspondência entre a germinação e a sobrevivência, em observações realizadas na geração $\mathrm{x}_{2}$, de grãos de arroz irradiadas com diferentes dosagens de radiação gama.

\subsection{Germinação das sementes na geração $M_{3}$}

Os valores percentuais obtidos pela contagem do número de sementes germinadas, aos 7 dias após a semeadura, constam da Tabela 6 . Nesta tabela são mostrados os valores médios em percentagem da germinação das sementes $M_{3}$ nas 3 dosagens de neutrons rāpidos empregadas e também es 
tes dados determinados em relação ao valor da testemunha considerada como 100\%. Esses valores da percentagem de germinação das sementes. $M_{3}$ foram re lacionados com as dosagens de radiações com neutrons recebidas pelas semen tes $M_{1}$ e são mostrados num gräfico que é apresentado na Figura 2.

TABELA 6 - Percentagem média de germinação de sementes $M_{3}$ nos tratamentos com diferentes dosagens de neutrons rāpidos.

\begin{tabular}{crcc}
\hline $\begin{array}{c}\text { Dosagem de } \\
\begin{array}{c}\text { Neutrons Rápidos } \\
(\text { krad) }\end{array}\end{array}$ & $\begin{array}{c}\text { Nọ de Sementes } \\
M_{3} \text { Semeadas }\end{array}$ & Percentagem & $\begin{array}{c}\text { Percentagem } \\
\text { em Relaçāo à } \\
\text { Tes temunha }\end{array}$ \\
\hline 0 & 16782 & 89,70 & 100,00 \\
1,0 & 73048 & 86,72 & 96,68 \\
2,0 & 14365 & 84,50 & 94,20 \\
\hline
\end{tabular}

Pode-se verificar que o aumento gradativo das dosagens de neutrons rápidos apliçadas às sementes $\mathrm{M}_{1}$ causou um decréscimo proporcional na percentagem de germinação das sementes $\mathrm{M}_{3}$. Embora, o decréscimo em germinação e sobrevivência, com o aumento da dosagem de radiação empregada, geralmente, seja encontrado quando se analisa a geração $M_{1}$, conforme salientado anteriormente.

A anālise estatística efetuada entre os 3 tratamentos consi derados mostrou um valor de $\dot{\chi}^{2}$ altamente significativo, o que levou à realização do teste de contingência entre as sementes germinadas e não germi nadas, com a finalidade de comparar-se o comportamento das sementes $\mathrm{M}_{3}$ em relação à germinação, quando as sementes foram submetidas às dosagens de 


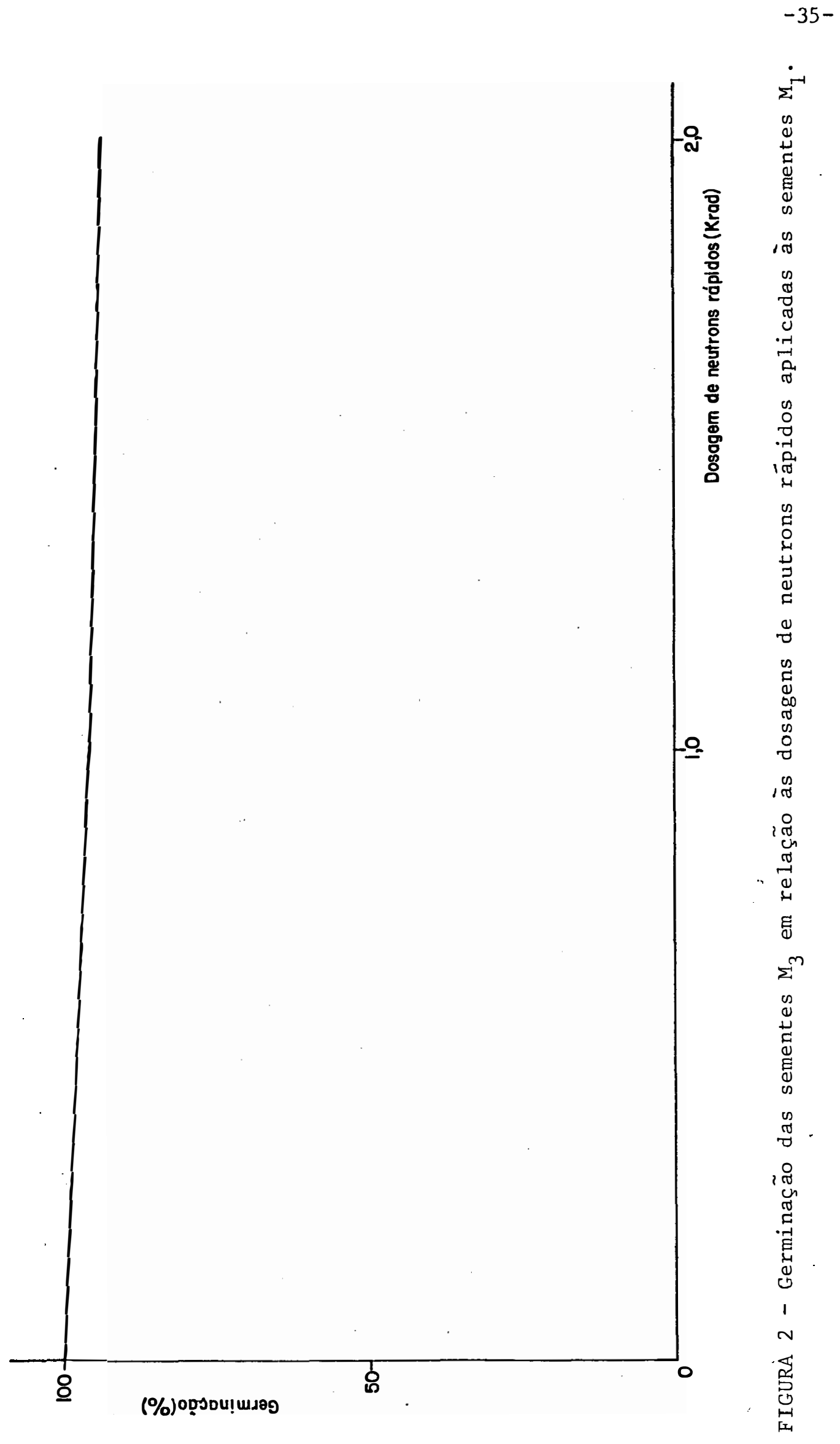


1,0 e 2,0 krad.de neutrons rápidos. Também foi feita a comparação entré as dosagens de 1,0 e $2,0 \mathrm{krad}$. Os valores de $\chi^{2}$ obtidos são mostrados na Tabela 7 .

Os resultados obtidos (Tabelas 6 e 7 e Figura 2) indicam que quanto à germinação das sementes $M_{3}$, o efeito foi mais acentuado para a dosagem mais elevada de $2,0 \mathrm{krad}$, e que os valores de $\chi^{2}$ foram significativos nos testes efetuados para as comparações das dosagens de 0 e $1,0 \mathrm{krad}$, 0 e $2,0 \mathrm{krad}$ e entre 1,0 e $2,0 \mathrm{krad}$. Isso evidencia que a aplicação das dí ferentes dosagens de radiação às sementes provocou diferenças no comportamento quanto à germinação das sementes $M_{3}$.

TABELA 7 - Valores de $\chi^{2}$ obtidos pelo teste de contingēncia entre todos os tratamentos, tomados 2 a 2 , para a germinação das sementes $M_{3}$.

Dosagem de

Neutrons Rāpidos

(krad)
1,0
2,0

$188,30 * *$

$49,60 * *$

**: significativo ao nível de $1 \%$ de probabilidade.

0 comportamento da germinação e da sobrevivência na geração $M_{2}$ e germinação na geração $M_{3}$, mostrou que houve um decréscimo nesses parâmetros com o aumento das dosagens de radiação aplicadas às sementes. Isso sugere algum efeito genético que seria transmitido às gerações poste riores. Tal assunto merece investigações mais profundas e cuidadosas, o 
que não foi feito no presente trabalho, pelo fato de ser outro o objetivo principal deste.

\subsection{Frequēncias de mutações na geração $M_{3}$}

Para a elaboração desta etapa do trabalho, os mutantes registrados foram, primeiramente, agrupados em 4 classes de mutações: clorofílicas, morfológicas, para hipocótilo verde e para hipocótilo rosa. No entanto, para os cálculos das frequências de mutações foram usados 2 critê rios: um, em que todas as mutações foram englobadas, sem distinção de clas ses, em cada tratamento; e outro no qual, para cada tratamento, as mutações foram consideradas separadamente para cada uma das classes.

Os números de plantas $M_{1}, M_{2}$ e de sementes $M_{3}$ semeadas, foram bastante variáveis entre os tratamentos. Estes números, bem como as frequências de mutações calculadas, segundo o método citado no item 3.2.2., são apresentados na Tabela 8 .

Foram construídos os grä́ficos, relacionando-se as dosagens de neutrons rápidos recebidas pelas sementes e as taxas de mutações obtidas na geração $M_{3}$, os quais são mostrados nas Figuras 3 e 4 .

Uma inspeção da Tabela 8 mostra que a frequência total de mutações foi mais alta no tratamento com dosagem mais elevada. Por outro lado, quando os cálculos das frequências de mutações foram realizados de acordo com o segundo critério utilizado, tais frequências para todas as classes de mutações, com exceção daquela para hipocótilo verde, foram mais elevadas na dosagem de 1,0 krad e decresceram na dosagem de 2,0 krad. Por 


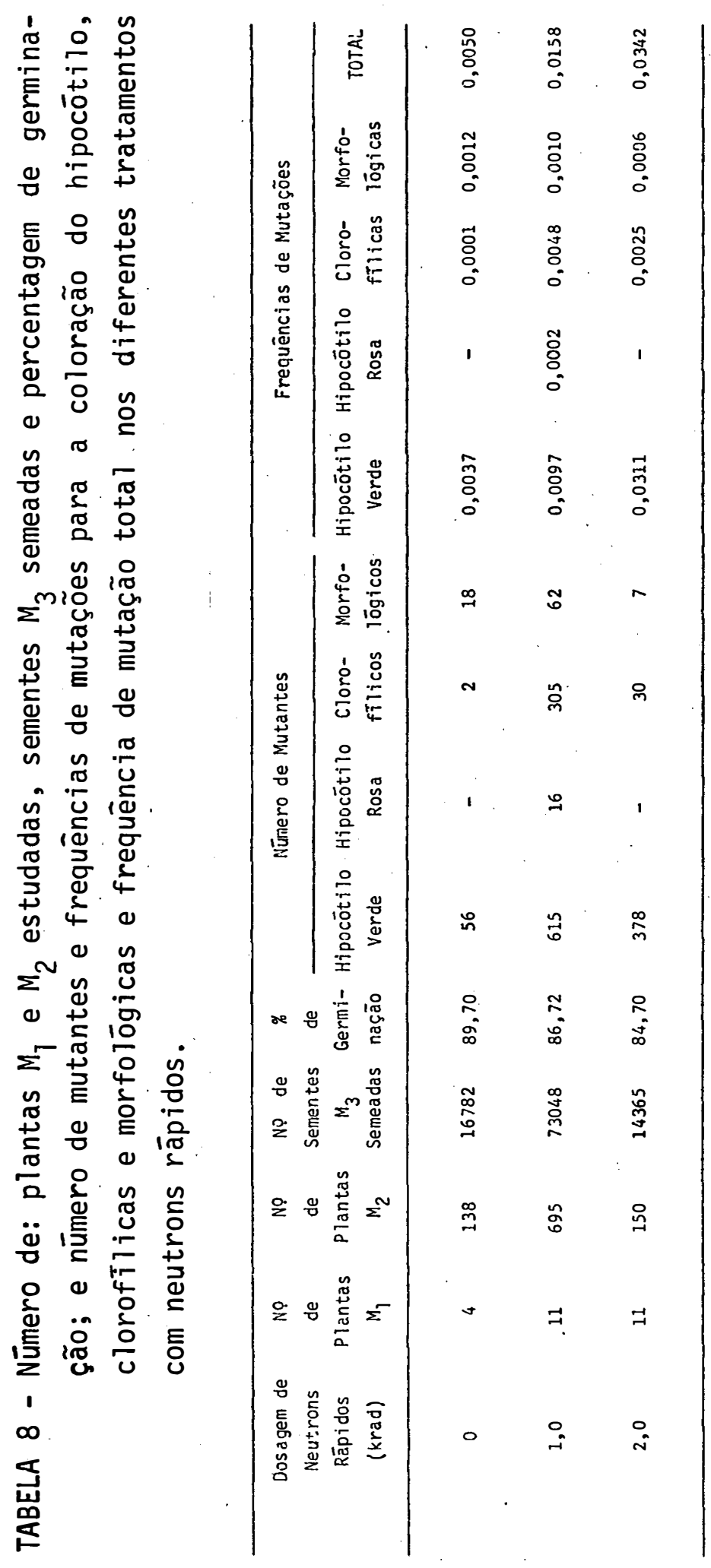




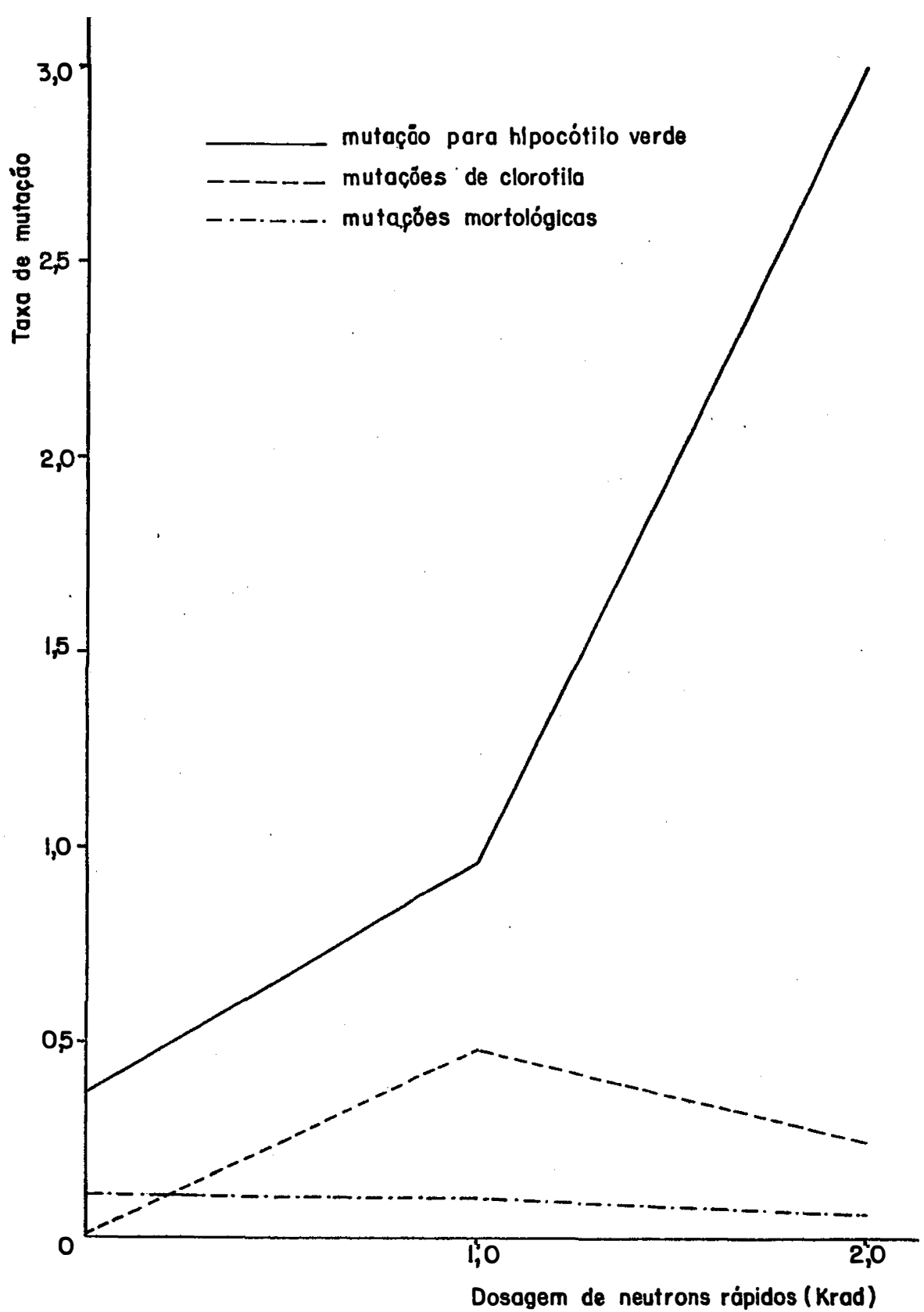

FIGURA 3 - Taxas de mutações determinadas na geração $M_{3}$, para as classes de mutações: morfológica, de clorofila e para hipocótilo verde. 


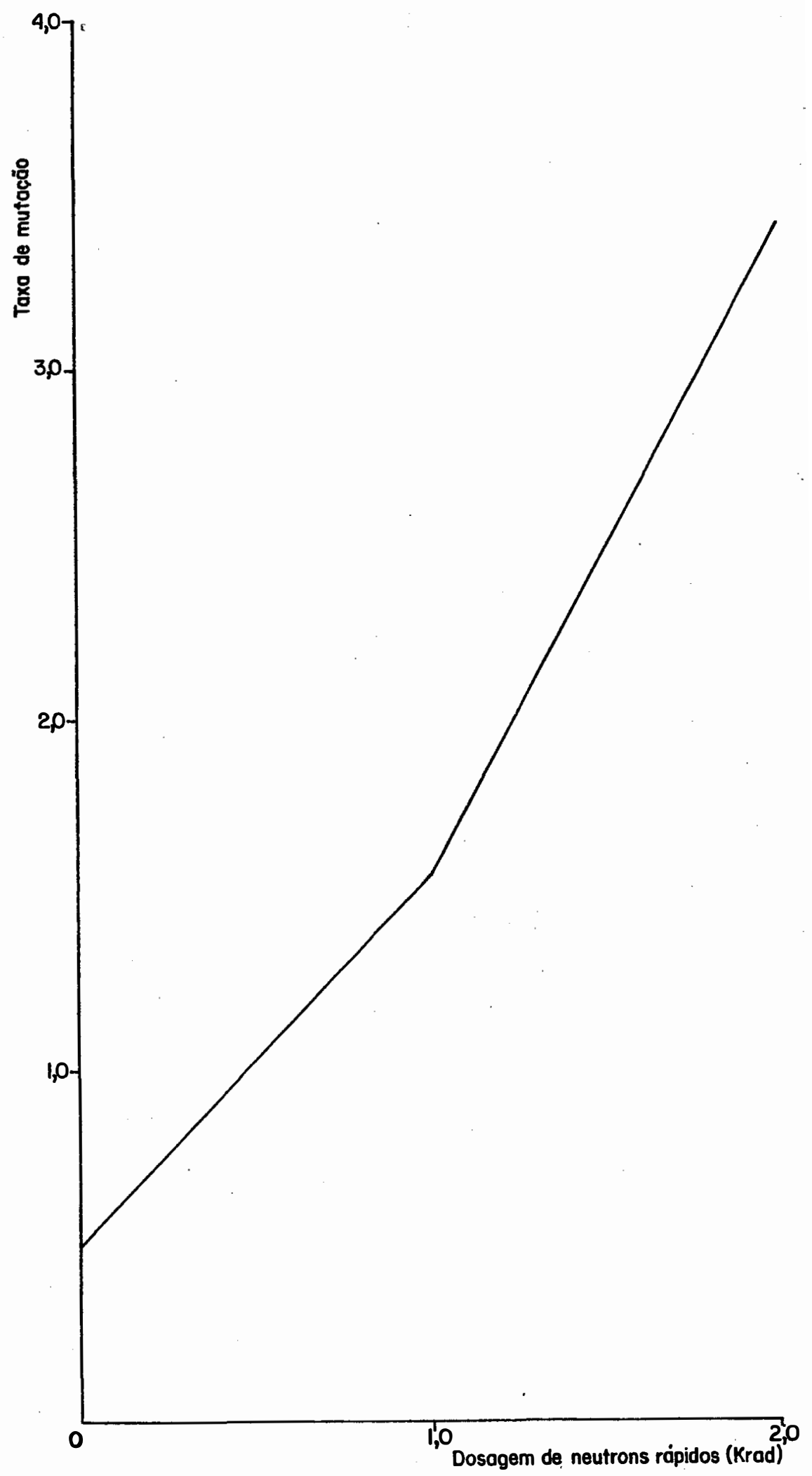

FIGURA 4 - Taxas de mutações determinadas na geração $M_{3}$ para todos os tipos de mutações observadas. 
tanto, foram obtidos resultados antagônicos entre os dois critérios empregados. Com base nos fatos de que as 4 classes de mutações estudadas no pre sente trabalho são devidas a mutações ocorridas em diferentes "loci" e que alguns genes são mais mutáveis e outros mais estáveis como será discutido mais adiante, os resultados mais coerentes são aqueles obtidos quando foram consideradas as 4 classes de mutações distintamente. Essa comparação entre as frequências de mutações obtidas através de duas diferentes maneiras, sugere que o método a ser usado, a título de calcular-se tais frequên cias, deve ser cuidadosamente escolhido pois, poderá levar a resultados e conclusões totalmente errôneos. Aqueles resultados obtidos e tomados como reais podem ser melhor compreendidos e explicados, levando-se em conta as observações feitas por alguns autores, entre os quais STADLER (1931), KONZAK e SINGLETON (1956), LEA (1956) e SMITH et alii (1964), de que a frequência de mutações induzidas por radiação ionizante é diretamente proporcional à dosagem empregada, porém em dosagens muito elevadas, a frequência diminui devido ao aumento da esterilidade causada por aberrações cromossômicas (MOH e NILAN, 1956; MATSUO et alii, 1958; EHRENBERG, 1961) ou à morte ou eliminação das células iniciais mutadas (GAUL, 1960).

Pode-se também observar que dentro da mesma dosagem as frequências diferiram bastante, entre os diversos tipos de mutações estudadas. Talvez isso se deva ao fato já bem conhecido de que os diferentes ge nes não são igualmente mutáveis conforme mencionado anteriormente. Por exemplo, quando estudou a taxa de mutação espontânea em milho,STADLER (1942) encontrou que o gene $\underline{r}$ (para coloração) é relativamente mutável, enquanto que os genes para endosperma "waxy" (wx) e "shrunken" (sh) são relativamen te estāveis. Também cox (1972) sugeriu que as taxas de mutação nos dife- 
rentes "loci", na mesma célula podem diferir consideravelmente, e que essas taxas são controladas geneticamente. Supôs então, que os genes nos ox ganismos superiores podem ser organizados não de acordo com a sua função, mas em diferentes segmentos do genoma que têm diferentes taxas de mutações intrínsecas.

Entre todos os tipos de mutações estudados, o que apresentou frequência mais elevada foi aquele para a coloração verde do hipocóti1o. Como salientado na Revisão de Literatura, este tipo de mutação tem uma peculiar importância no melhoramento do feijoeiro, por estar correlacio nada com a coloração do tegumento da semente. Este fenômeno é, provave1mente, devido ao efeito pleiotrópico do fator recessivo $\underline{p}$ que determina a ausência de coloração. Assim, experimentalmente, a herança da coloração do tegumento pode ser estudada através do estudo da herança da coloração do hipocótilo.

E bem conhecido o fato de que muitas cultivares de feijão preto têm uma resistência mais alta a doenças e maior capacidade de produção' do que as variedades de outras cores (YGLESIAS, 1964), mas por causa de sua coloração o cultivo dessas variedades é limitado em muitas regiões, desde que a maioria do mercado consumidor tem preferência pelas variedades de feijão branco, vermelho ou amarelo. Por esse motivo, é altamente vanta josa a obtenção de mutantes a partir de feijão com tegumento preto, como já tem sido conseguido por alguns autores já mencionados, porque desse modo há oportunidade de isolar mutantes que, conservando as características favorạ veis do original, apresente uma coloração do tegumento que permita a sua aceitação por parte da população que habitualmente não consome o feijão pre to. 
A Figura 5 mostra uma fotografia de um mutante para colora ção rosa do hipocōtilo.

Quanto aos mutantes de clorofila foram encontrados os mais diversos tipos como por exemplo: albina (Figura 6), xanta (Figura 7), viri dis, rosa, verde escuro, albina com hipocótilo de coloração normal (Figura 8), rosa-verde (Figura 9), verde-rosa, verde-xanta (Figura 10), maculada (Figura 11), e mutante com folhas de coloração verde normal, folhas albinas e algumas verdes com manchas brancas (Figura 12).

As plantas da cultivar original Costa Rica apresentam duas folhas primārias cordiformes e as demais.trifolioladas. Os folíolos são inteiros, deltóides, acuminados, sendo um terminal e os outros dois laterais e opostos. Entre os mutantes morfológicos foram observados aqueles com folhas primárias deltiformes. Vale a pena ressaltar que TULMANN NETO (1979) selecionou na cultivar Carioca, apōs o emprego de agentes muta gênicos, um mutante morfológico deste tipo, fazendo referência a uma possí vel associação entre esta forma das folhas primārias com a tolerância ao mosaico dourado do feijão. Outros mutantes morfológicos obtidos foram aqueles com 3, 4 ou 6 folhas primárias, os unifoliolares e os com folíolo bipartido.

Uma vista geral do ensaio mostrando as plântulas $M_{3}$ em casa de vegetação é apresentada na Figura 13.

0 teste de contingência entre as plântulas mutantes e não mutantes, considerando-se todas as classes de mutações em conjun to, em todos os tratamentos, resultou num valor de $\chi^{2}$ altamente significativo. Assim, procedeu-se à comparação entre as frequências de mutações ob 


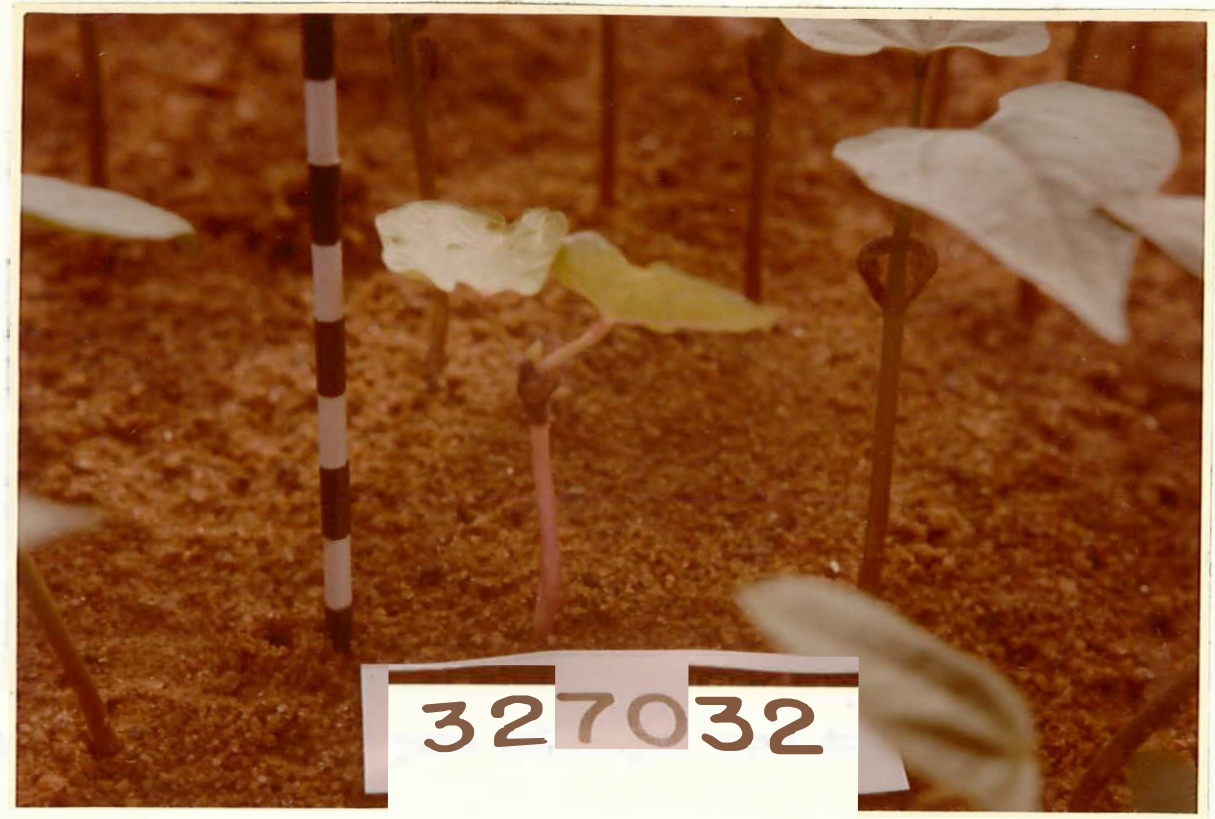

FIGURA 5 - Mutante para coloração rosa do hipocótilo.

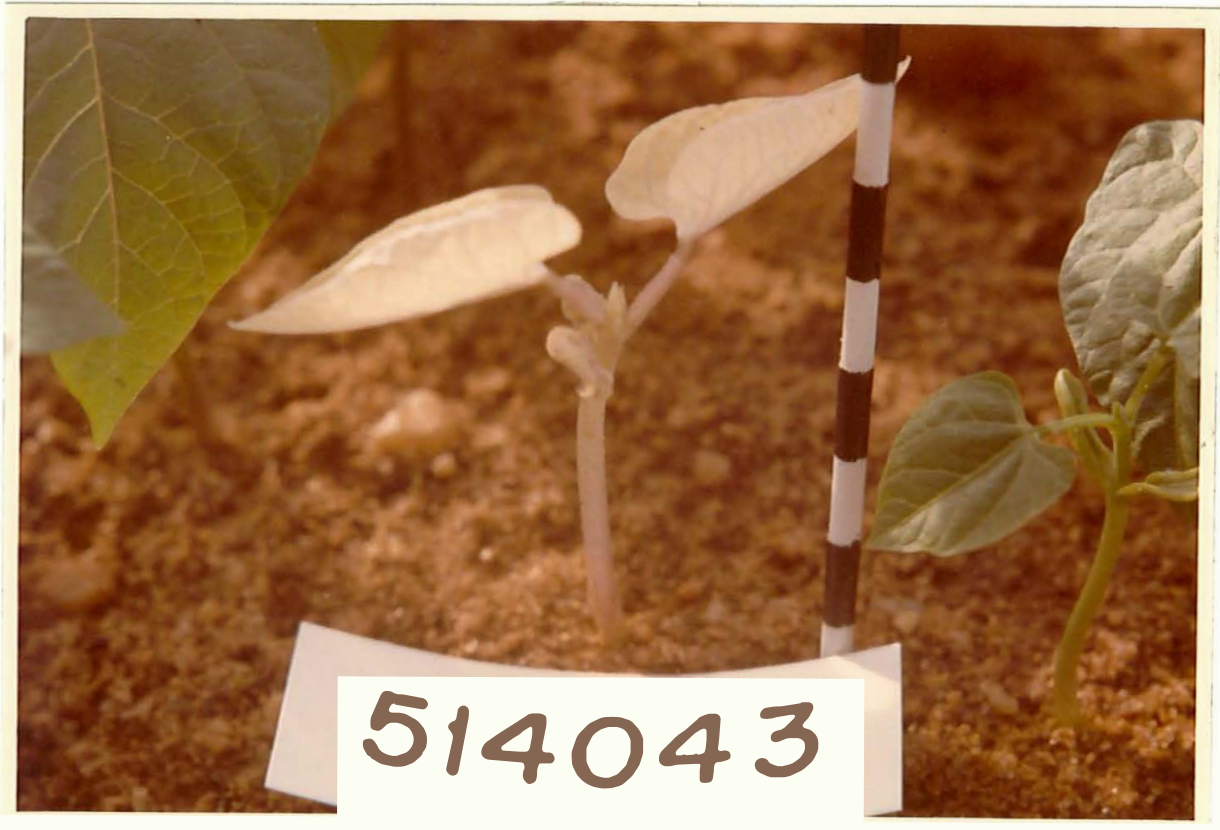

FIGURA 6 - Mutante albino. 


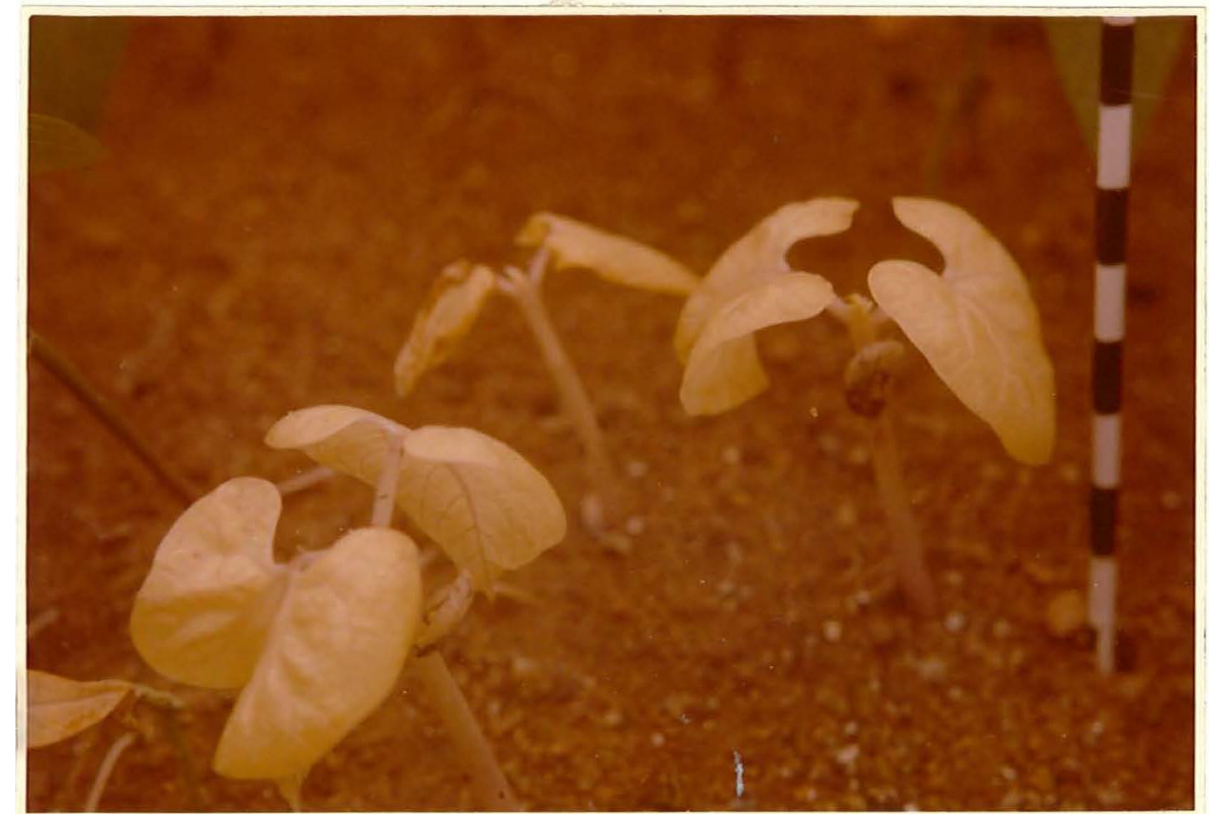

FIGURA 7 - Mutante xanta. 


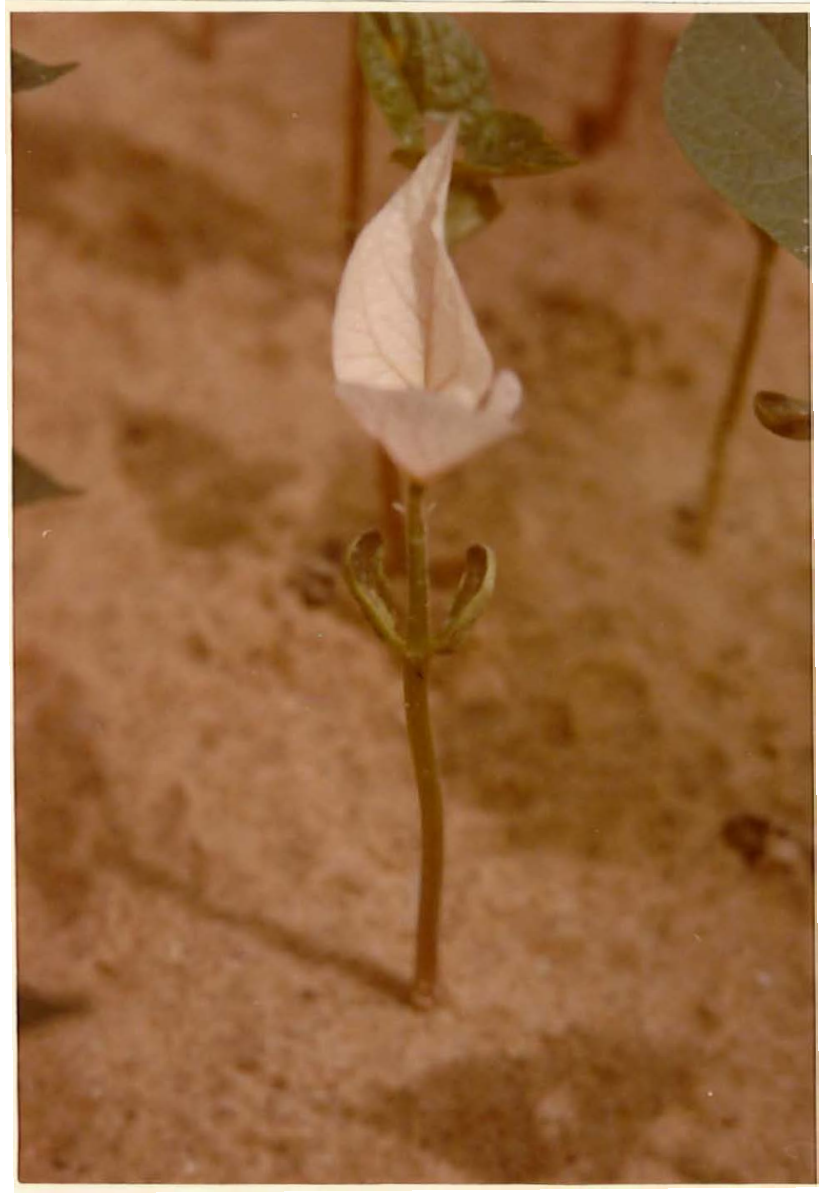

FIGURA 8 - Mutante com folhas primárias al binas e hipocótilo com coloração verde normal. 


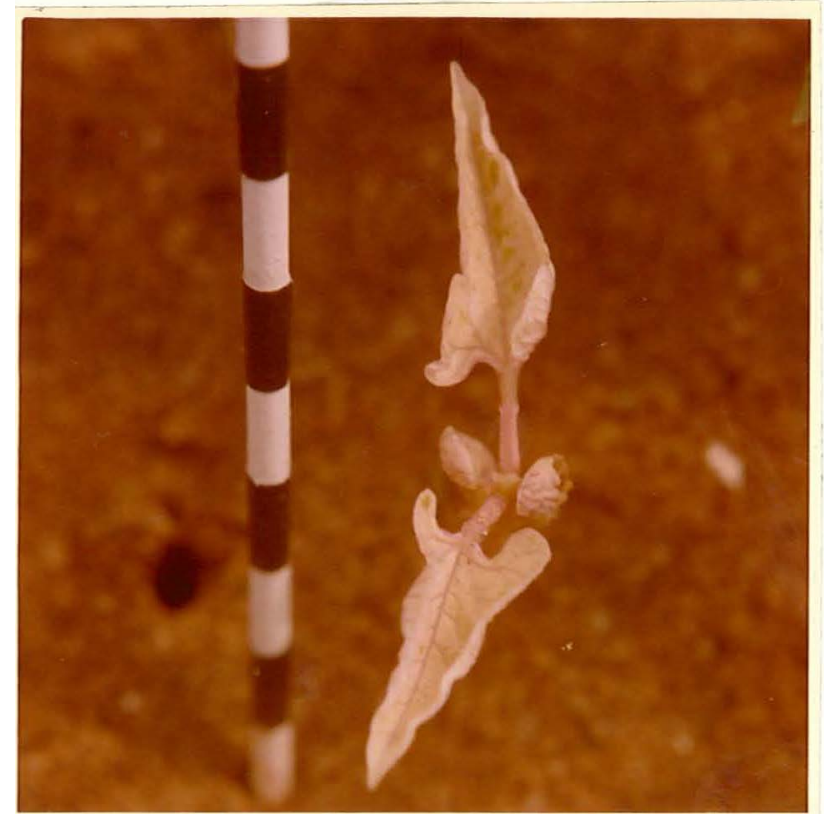

FIGURA 9 - Mutante rosa-verde.

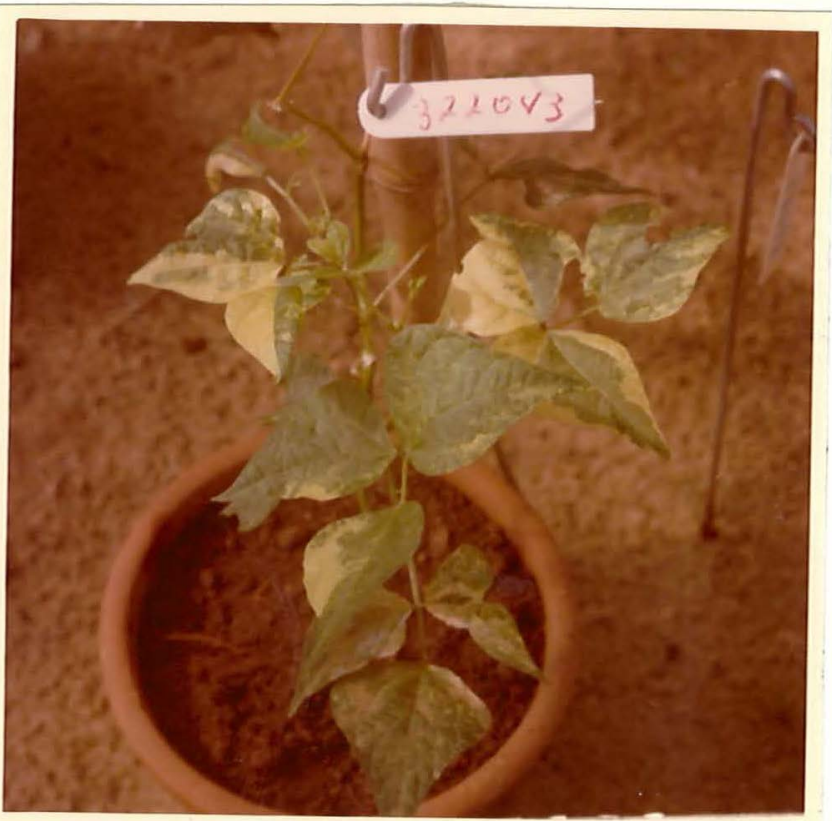

FIGURA 10 - Mutante verde-xanta. 


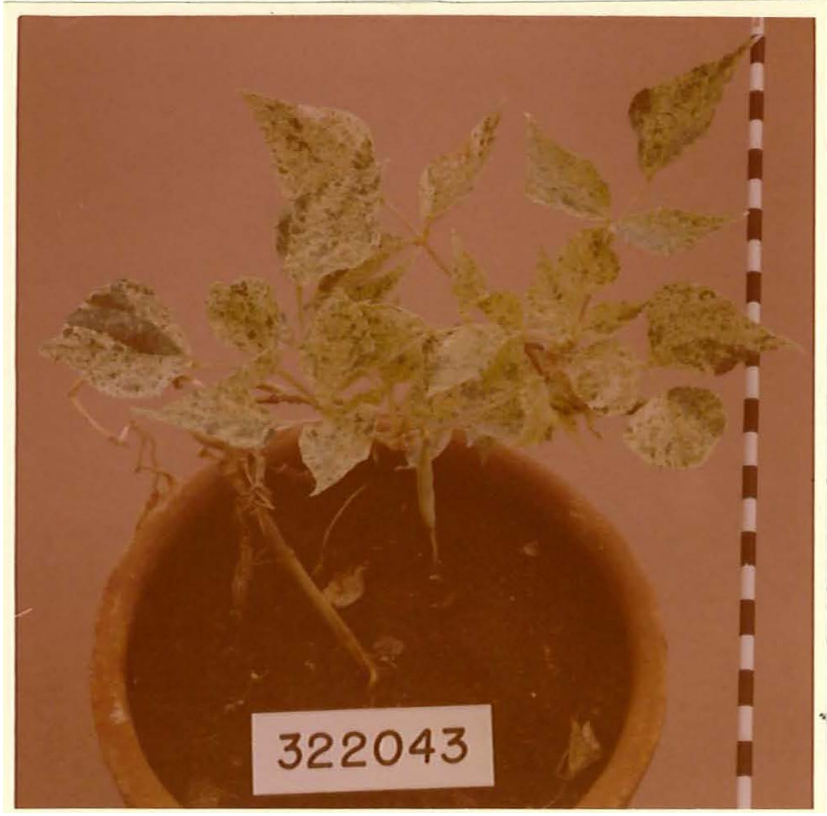

FIGURA 11 - Mutante maculada. 


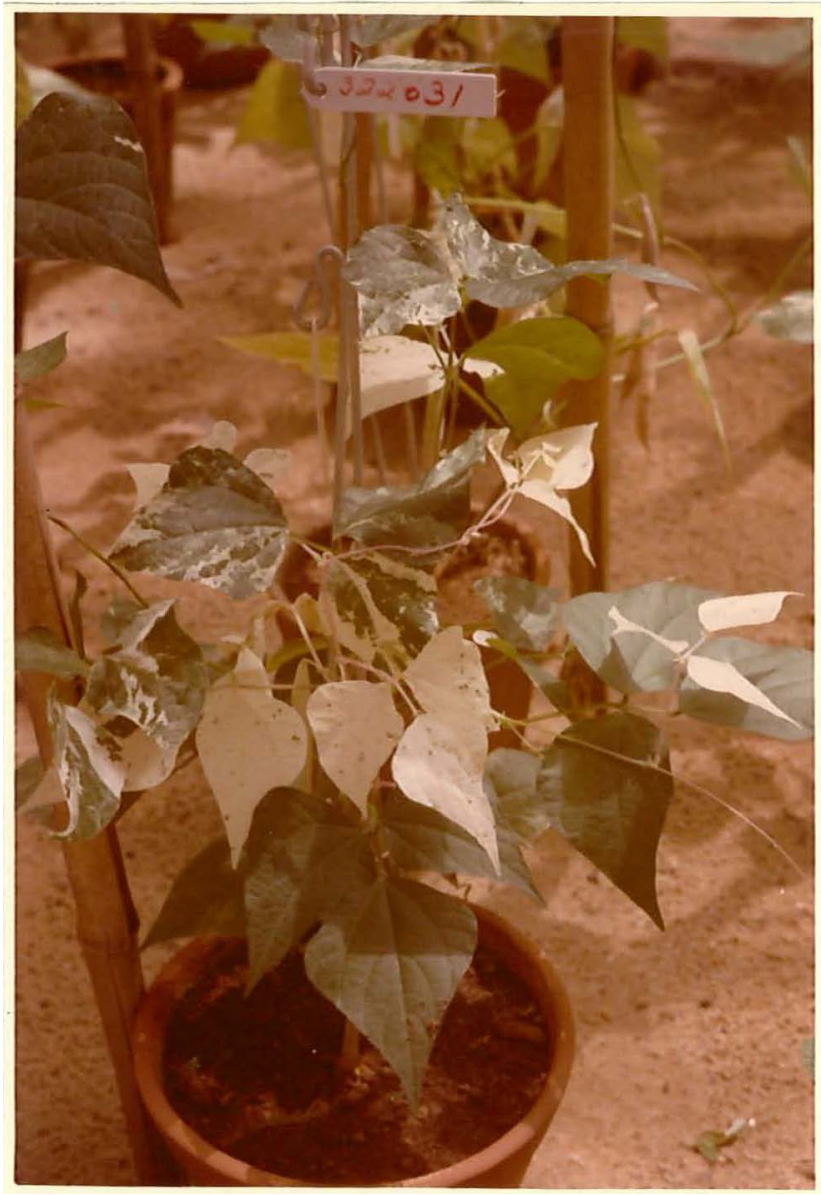

FIGURA 12 - Mutante com folhas de colora ção verde normal, albinas e al binas com manchas verdes e ver des com manchas brancas. 


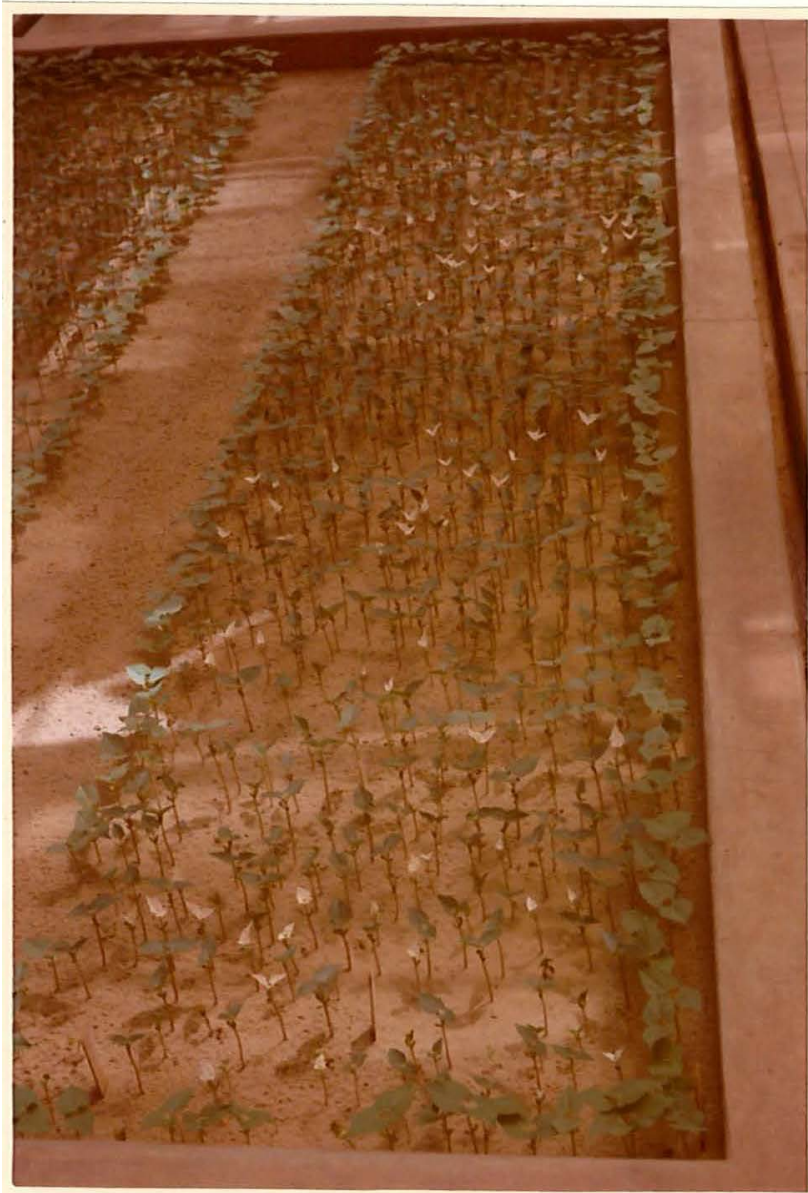

FIGURA 13 - Vista geral do ensaio, instalado em casa de vegetação, mostrando as plântulas $M_{3}$. 
servadas na testemunha com as das dosagens de 1,0 e 2,0 krad e entre estas 2 últimas dosagens. Os valores de $\chi^{2}$ obtidos e apresentados na Tabela 9, foram significatịvos ao nível de $1 \%$ de probabilidade, para todas as comparações. Isso indica que as diferentes dosagens provocaram diferentes respostas em relação à frequência de mutações, quando sementes $M_{1}$ foram submetidas às diversas dosagens de neutrons rápidos.

TABELA 9 - Valores de $\chi^{2}$ obtidos pelo teste de contingência entre todos os tratamentos tomados 2 a 2 , para as frequências de mutações, determinadas na geração $M_{3}$.

\begin{tabular}{ccc}
\hline $\begin{array}{c}\text { Dosagem de } \\
\text { Neutrons Rāpidos } \\
(\text { krad) }\end{array}$ & 1,0 & 2,0 \\
\hline 0 & $103,17 * *$ & $321,79 * *$ \\
1,0 & - & $188,42 * *$ \\
\hline
\end{tabular}

**: significativo ao nível de $1 \%$ de probabilidàde.

4.5. Taxas de segregação, nūmero de cēlulas iniciais presentes no em brião e estrutura quimérica das plantas $M_{1}$

A semente é constituída de numerosas células e no embrião as diferentes regiões dos meristemas têm a potencialidade de dar origem a uma certa parte da planta. Após a irradiação das sementes é, portanto, es perada que a planta $M_{1}$ carregue uma mutação induzida somente em certas 
partes, e outras partes sendo normais ou mutadas diferentemente. A região que contém a mutação é referida como sendo um setor mutado da planta que é geneticamente quimera. Portanto, o primeiro passo do pesquisador em um trabalho sobre mutação é determinar a frequência de células que carregam as mutações induzidas.

-A grande maioria das mutações gênicas induzidas são recessi vas, consequentemente não podem ser detectadas até a geração $M_{2}$. Entretanto, o interesse real não consiste em determinar a frequência de mutação em termos do número total de células no embrião, mas sim daquelas iniciais que formarão a chamada linhagem germinativa, ou seja, somente a frequência de mutação daquelas iniciais no embrião que formarão, em ūltima análise, o tecido generativo da inflorescência. o número de células iniciais expressa o número médio de células do qual deriva a geração $\mathrm{M}_{2}$ (GAUL, 1963), ou o número geneticamente efetivo (LI e REDEI, 1969, citado por YAMAGUCHI em 1980). Assim, segundo esses autores, as células iniciais são aquelas que têm a capacidade de originar as linhagens celulares que podem ser detectadas, e o seu número não corresponde necessariamente ao número original de células iniciais presentes no momento do tratamento, isto é, o termo não tem o mesmo significado daquele usado pelos botânicos para indicar as célü las que irão formar um certo órgão.

Ocorrendo mutações nas células iniciais elas poderão sofrer seleção intra-somática (KAPLAN, 1951) ou seleção diplôntica (GAUL, 1957), durante o desenvolvimento das sementes, assim como a seleção haplôntica (GAUL, 1957) na meiose. Supondo que esses dois tipos de seleção não ocorram,a taxa de segregação esperada na geração $M_{2}$, de fenótipos normais para mutantes, será de 3:1 se na formação do tecido generativo estiver en 
volvida uma única célula inicial ou se a mutação em questão for recessiva monogênica, como no caso da mutação de clorofila. Se mais do que uma inicial tomar parte na formação desse tecido, a taxa de segregação será menor que $25 \%$, desde que as células não sofram a mesma mutação simultaneamente. Se houver seleção haplôntica e/ou diplôntica entre as células mutadas e não mutadas, a taxa de segregação sofrerā uma diminuição em virtude da elimina ção das células, a não ser que as células iniciais já estejam bem diferenciadas no momento do tratamento como foi verificado por GAUL (1959). Neste caso, as células normais não poderão substituir aquelas mutadas que foram injuriadas ou lesadas pelo tratamento mutagênico, não havendo, portanto, nenhum dos dois tipos de seleção, fato este que parece ter acontecido no experimento em pauta.

Para a anālise das taxas de segregação, foram usadas todas as mutações encontradas, isto é, aquelas que segregaram próximo a proporção de $3: 1$ como tambēm aquelas extremamente distantes da referida proporção. Esses resultados são mostrados nas Tabelas 10, 11, 12 e 13.

Na Tabela 10 são apresentadas as taxas de segregação para os diferentes tipos de mutações estudados na geração $M_{3}$, para cada um dos tratamentos recebidos pelas sementes na geração $M_{1}$.

Através dos resultados das contagens dos números de mutan tes agrupados em 5 classes assim distribuídas: hipocótilo verde, hipocótilo rosa, clorofílicas letais, clorofílicas não-letais e morfológicas, foram determinadas as taxas de segregação que constam da Tabela 11 . Por observação dessa tabela pode-se verificar que a taxa de segregação sofreu uma elevação na dosagem de 2,0 krad em relação à dosagem de 1,0 krad, consi derando-se as mutações para coloração verde do hipocótilo e clorofílicas 
TABELA 10 - Taxas de segregação para todos os tipos de mutações estudadós em plāntulas $M_{3}$, nos tratamentos com dosagens de neutrons râpidos.

Tipo de Mutação

Dosagem de Neutrons Rápidos (krad)

\begin{tabular}{lll}
\hline 0 & 1,0 & 2,0 \\
\hline
\end{tabular}

Hipocótilo verde

0,3998

1,2931

3,8630

Hipocótilo rosa

$-$

0,2145

Viridis

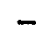

0,1476

Xan ta

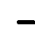

0,0800

1,0798

Verde-xanta

0,0197

0,0700

0,1566

Verde com manchas mais claras

0,0197

0,3996

Rosa

0,0197

0,5582

Verde escuro

$-$

0,3996

0,3886

Verde-xanta e manchas rosa

$-$

0,1161

- $\quad 0,1633$

Unifoliar

0,1204

0,0600

0,1137

4 Folhas primárias

- $\quad 0,0300$

6 Folhas primárias

0,0200

Folha primária reduzida

$\begin{array}{ll}- & 0,3538\end{array}$

Folha bifurcada

0,0200

0,0300 
letais. No caso das clorofílicas não-letais, houve um decréscimo com o au mento da dosagem sendo que as morfológicas praticamente, não foram influenciadas pela dosagem, em relação a taxa de segregação. Assim, os dados desta tabela indicam que não ocorreu um aumento proporcional da taxa de se gregação em relação à dosagem, para todos os tipos de mutações considera dos.

TABELA 11 - Taxas de segregação determinadas em plāntulas $M_{3}$ nas classes de mutações observadas nos diferentes tratamentos com neutrons rápidos.

Classe de Mutação

Dosagem de Neutrons Rāpidos (krad)

$1,0 \quad 2,0$

$\begin{array}{lccc}\text { Hipocótilo verde } & 0,3998 & 1,2931 & 3,8630 \\ \text { Hipocótilo rosa } & - & 0,2145 & - \\ \text { Clorofílicas letais } & 0,0197 & 0,4219 & 1,0797 \\ \text { Clorofílicas não-letais } & 0,0197 & 0,3269 & 0,2420 \\ \text { Morfológicas } & 0,1445 & 0,1128 & 0,1137\end{array}$

Da Tabela 12, constam as taxas de segregação calculadas de modo a englobar todos os tipos de mutações estudados, em cada um dos trata mentos. Os dados obtidos indicam que ocorreu uma elevação na taxa de se gregação com o aumento da dosagem de radiação empregada.

Esses resultados não são compatíveis com as conclusões de MOTTO et alii (1975), onde a taxa de segregação não foi dependente da dose 
do mutagênico por eles utilizado: Como foi mostrado, para alguns tipos de mutações estudadas no presente trabalho, tais conclusões não podem ser aplicadas.

TABELA 12 - Número de plantas $M_{1}$ e $M_{2}$ estudadas, sementes $M_{3}$ semeadas, per centagem de germinação, número de mutantes e taxas de segregação para todos os tipos de mutações considerados em conjunto, nos diferentes tratamentos com neutrons rápidos.

\begin{tabular}{ccccccc}
\hline $\begin{array}{c}\text { Dosagem de } \\
\begin{array}{c}\text { Neutrons } \\
\text { Räpidos* }\end{array}\end{array}$ & $\begin{array}{c}\text { Nọ de } \\
\text { Plantas } \\
M_{1}\end{array}$ & $\begin{array}{c}\text { Nọ de } \\
\text { Plantas } \\
M_{2}\end{array}$ & $\begin{array}{c}\text { Nọ de } \\
\text { Sementes M } \\
\text { Semeadas }\end{array}$ & $\begin{array}{c}\text { Percen- } \\
\text { tagem de } \\
\text { Germinação }\end{array}$ & $\begin{array}{c}\text { No de } \\
\text { Mutan } \\
\text { tes }\end{array}$ & $\begin{array}{c}\text { Taxa de } \\
\text { Segre- } \\
\text { gação }\end{array}$ \\
1,0 & 10 & 651 & 69029 & 85,52 & 1007 & 1,7057 \\
2,0 & 8 & 115 & 11424 & 85,62 & 415 & 4,2411 \\
* em krad & & & & & &
\end{tabular}

Na Tabela 13 são mostradas as taxas de segregação e os núme ros de células iniciais separadamente, para plantas com uma ramificação prí mária, com 2, com 3 e com mais do que 3 ramificações primárias em duas dosagens de neutrons rápidos, considerando-se as seguintes classes de mutações: hipocōtilo verde, hipocótilo rosa, clorofílicas letais, clorofílicas não-letais e morfológicas. Pelo menos em relação à dosagem de 2,0 krad, de modo geral, a taxa de segregação decresceu com o aumento dos números de ramificações primārias das plantas. Considerando-se uma determinada classe de mutação, quanto maior o número de ramificações primárias que a planta possui maior o número de células iniciais. Essas observações sugerem 


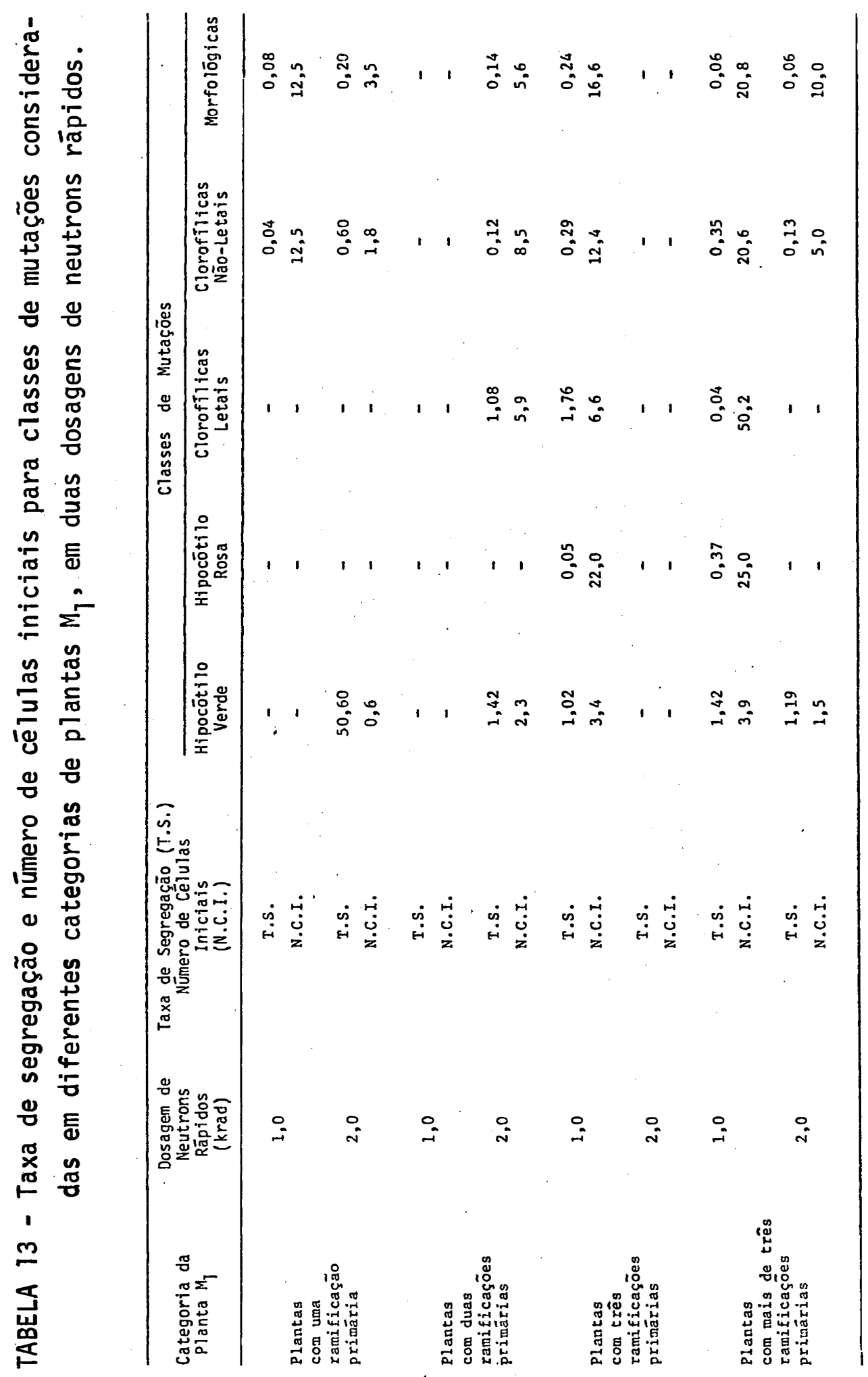


que o nümero de células iniciais que sobrevivem na região meristemática de um embrião de feijão após os tratamentos com neutrons rápidos, está relacionado ao subsequente grau de desenvolvimento da planta, como já foi demonstrado em 1975 por MOTTO et alii, utilizando mutagênicos químicos.

Os valores médios dos números de células iniciais, calculados para cada tratamento para os diferentes țipos de mutação, constam da Tabela 14. Pode-se verificar que para os tratamentos com 2,0 krad os núme ros encontrados de células iniciais presentes no embrião, para as mutações estudadas, foram menores do que para os tratamentos com $1,0 \mathrm{krad}$.

TABELA 14 - Número médio de cēlulas iniciais para os diferentes tipos de mutações em 2 dosagens de neutrons rápidos.

Tipo de Mutação

Dosagem de Neutrons Rápidos (krad)

$1,0 \quad 2,0$

Hipocótilo verde

$3,7 \quad 1,9$

Xanta

36,8

5,9

Verde-xanta

17,1

6,5

3 Folhas primárias

13,1

4,9

0 aumento das dosagens de radiação acarreta uma elevação na probabilidade de aparecimento de danos letais nas células mutadas, as quais não poderão ser substituídas devido ao seu estado diferenciado. Con sequentemente, a taxa de segregação aumenta e o número de células iniciais 
sobreviventes diminui.

Os resultados expressos nas Tabelas 12, 13 e 14 evidenciam que de um modo geral, o tratamento com 2,0 krad de neutrons rápidos foi mais eficiente, causando uma maior taxa de segregação e, consequentemente, diminuição do número de células iniciais, quando comparado com a dosagem de $1,0 \mathrm{krad}$. Tal fato leva à conclusão de que no momento dos tratamentos mutagênicos com neutrons rápidos, as células iniciais presentes no embrião das sementes de feijão, jā se encontravam diferenciadas. ANDo (1970) jā havia chegado a essa conclusão em relação às células iniciais do embrião de arroz. E um fato bem conhecido que as mutações ocorrem ao acaso, e quan do determinadas pelos métodos usuais sugeridos por GAUL (1960), aparecem em baixas frequências, mas o presente trabalho mostra que as mutações por célula ocorrem em frequências relativamente altas. Deste modo é válida a sugestão que ao conduzir-se um experimento com neutrons rápidos, em feijão, deve-se usar dosagem alta que possibilite o emprego de menor número de sementes e oferece oportunidade de obtenção de mais alta frequência de mutan tes por célula.

Em pesquisa sobre a formação de quimera, tem sido dispensada atenção especial durante os ûltimos anos à estimativa do tamanho do setor mutado. Duas estimativas denominadas "a posteriori" e "a priori" têm sido usadas em adição à clássica estimativa baseada nas taxas de segrega ção $M_{2}$ de mutações de clorofila, isto é, sobre a relação inversa entre des vios de 20 - 25\% em razões de segregações $M_{2}$ (índice para espiga heterozigota) e tamanho do setor mutado (menoṛ o desvio, maior o tamanho). A estí mativa "a posteriori" é fornecida pelo auxílio de uma anālise "topográfica" que consiste essencialmente de localizar a posição de todos os mutantes 
de clorofila dentro de uma inflorescência $M_{1}$ (SCARASCIA-MUGNOZZA, 1969).

Foram escolhidas algumas plantas com a finalidade de se demonstrar a anālise topogrä́fica realizada em todas as plantas. Oś esquemas dessas análises são mostrados nas Figuras de números 14 a 23.

A Figura 14 mostra a representação esquemática, de heterozi gotos para o mesmo carāter mutante (hipocōtilo verde) em 4 ramificações pri márias. Este fato pode ser notado em outros esquemas representativos da estrutura quimérica das plantas $M_{1}$, mostrados nas Figuras 15, 17, 18, 19 e 20. A opinião de MOTTo et alii (1975) a esse respeito é que tais eventos múltiplos podem derivar de mutações independentes ou podem vir de uma origem comum, isto é, todos os ramos envolvidos serem originários das mesmas células iniciais. Por outro lado, apareceram sementes heterozigotas para dois ou mais tipos de mutações, como pode ser observado por exemplo na plan ta nọ 5.14, cujas anālises topogrä́ficas são mostradas nas Figuras 21, 22 e 23. Pelas referidas figuras pode-se verificar que existe uma mesma semente heterozigota para os caracteres mutantes trifoliar e xanta, simultaneamente. Isso conduz a duas linhas de pensamento: uma delas é que uma mesma célula inicial sofreu dois ou mais tipos de mutações, e a outra é que a ra mificação primária tenha se originado de mais do que uma célula inicial, sendo que cada uma delas tenha sofrido um tipo de mutação. Pelo que se sa be a respeito da probabilidade, infinitamente pequena, de duas mutações diferentes ocorrer na mesma célula, parece mais lógico que a segunda alter nativa possa ser a mais aceita, isto é, que uma ramificação primāria tenha mais do que uma célula inicial envolvida na sua formação. 


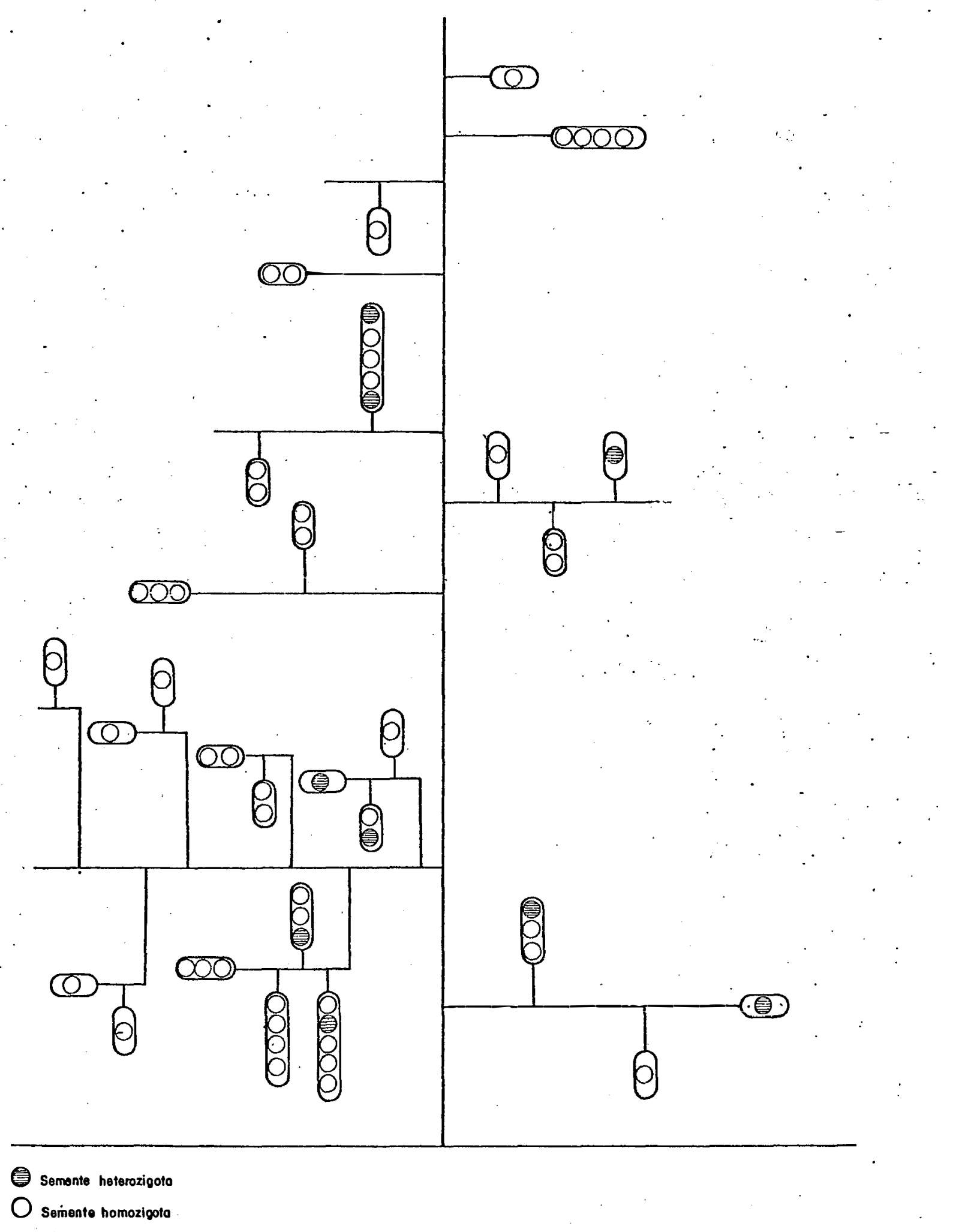

FIGURA 14 - Representação esquemática da anālise topogrä́ica da planta M no 3.21, mostrando sementes $\mathrm{M}_{2}$ heterozigotas e homizogotas dominantes para o caráter mutante hipocótilo verde. 


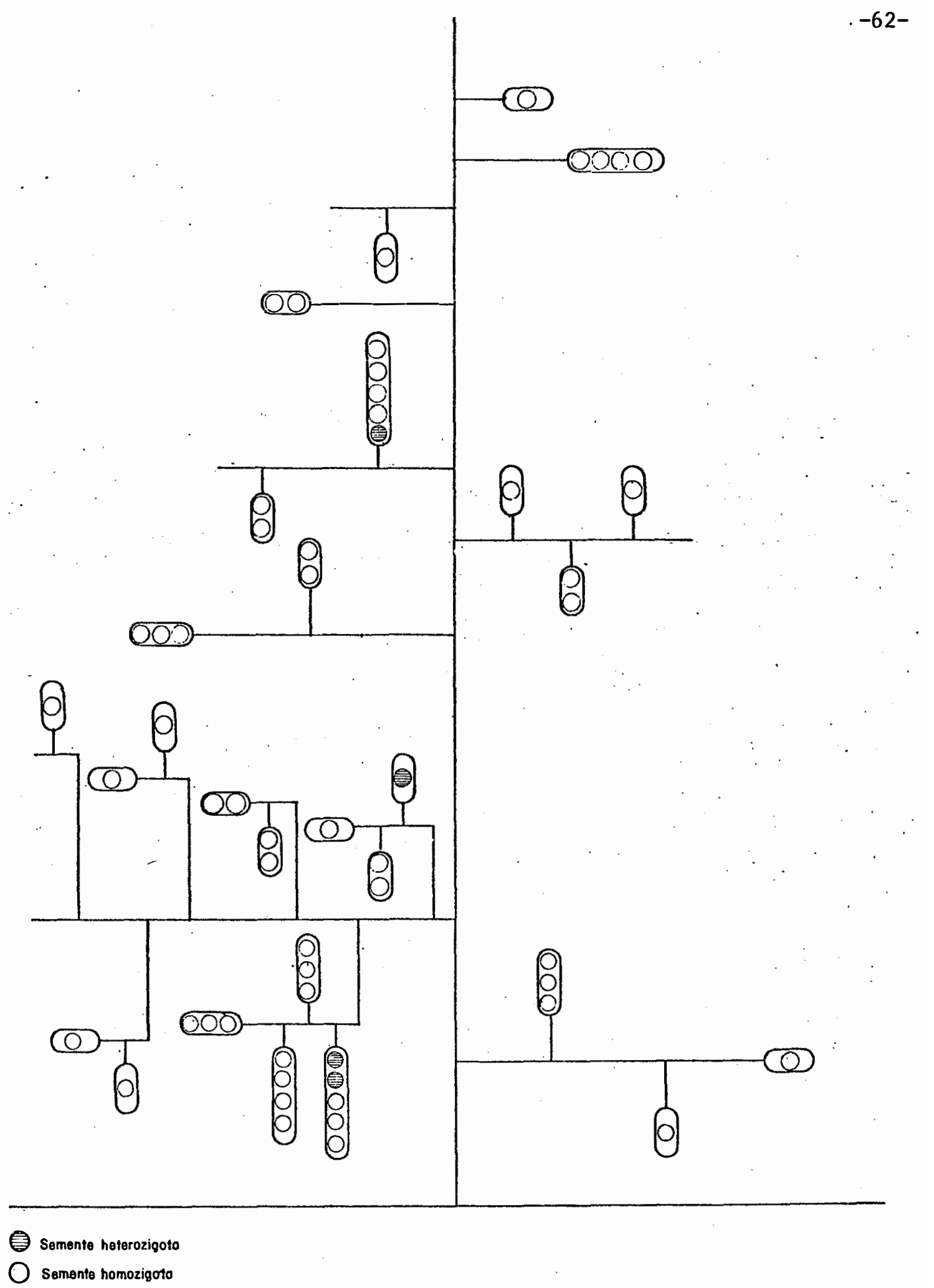

FIGURA 15 - Representação esquemática da anālise topogräfica da planta M no 3.21, mostrando sementes $\mathrm{M}_{2}$ heterozigotas e. homozigotas dominantes 'para a mutação verde-xanta. 


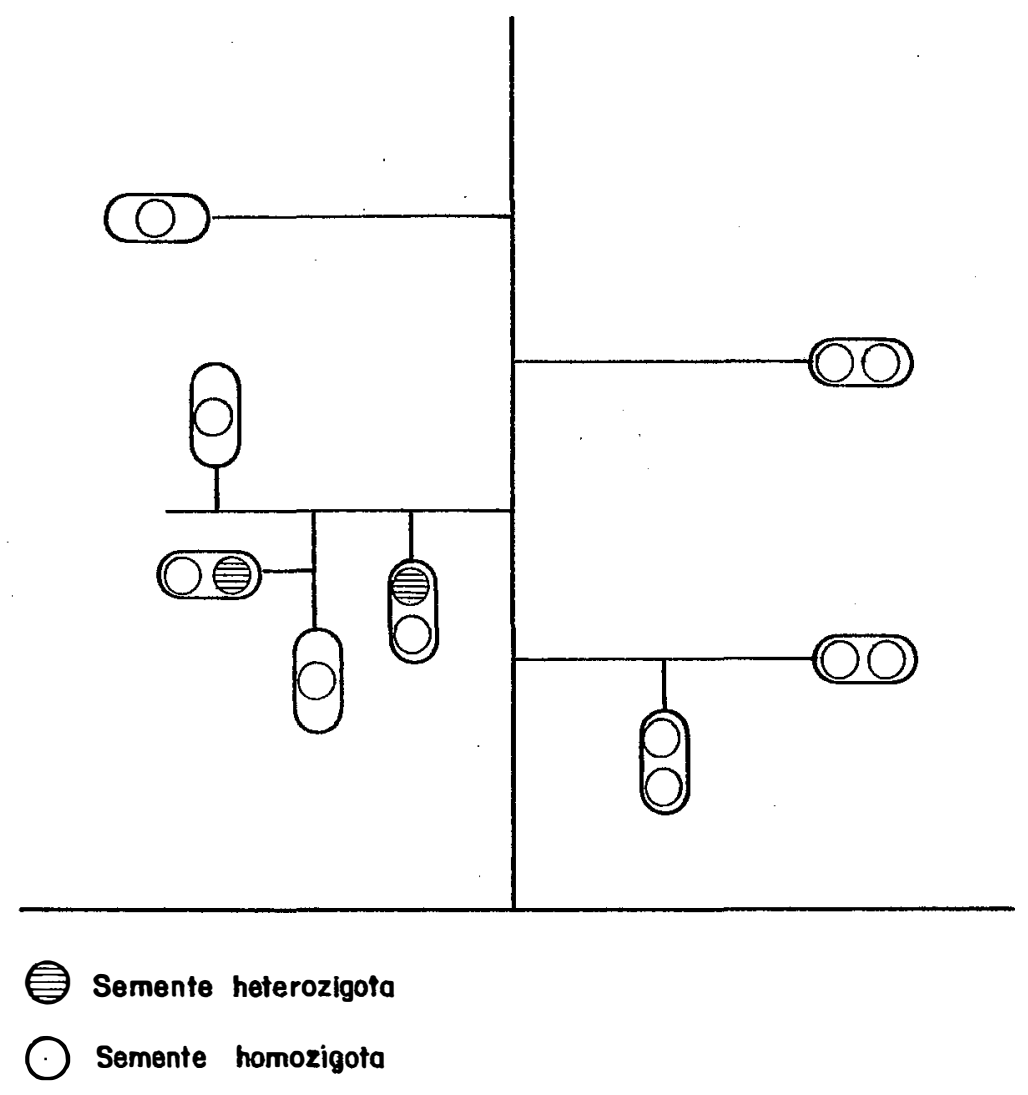

FIGURA 16 - Representação esquemática da anālise topogrä́ica da planta $M_{1}$ no 3.24, mostrando sementes $M_{2}$ heterozigotas e homozigo tas dominantes para a mutação morfológica trifoliar (3 folhas primárias). 


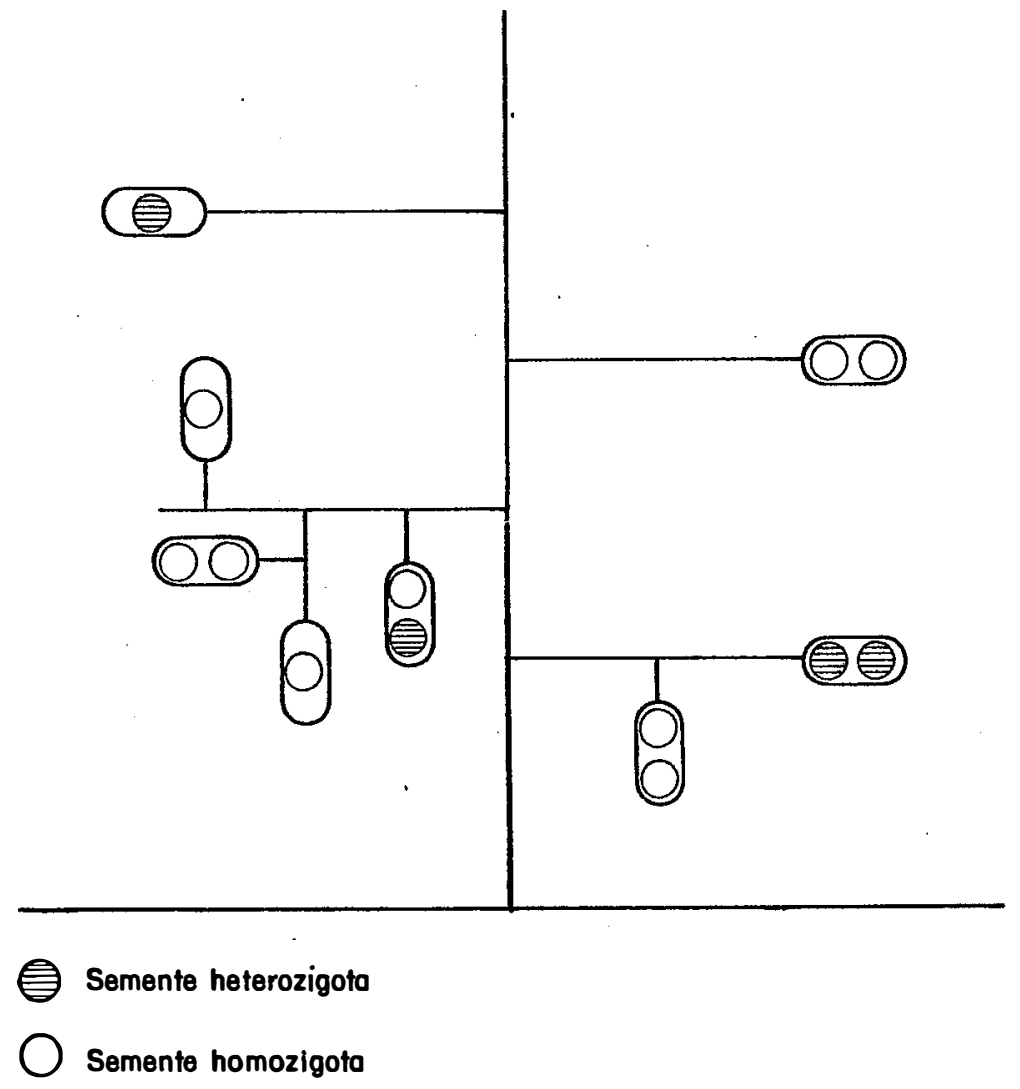

FIGURA 17 - Representação esquemática da anālise topogrā́ica da planta M n? 3.24, mostrando sementes $M_{2}$ heterozigotas e homozigotas dominantes para o carāter mutante viridis. 


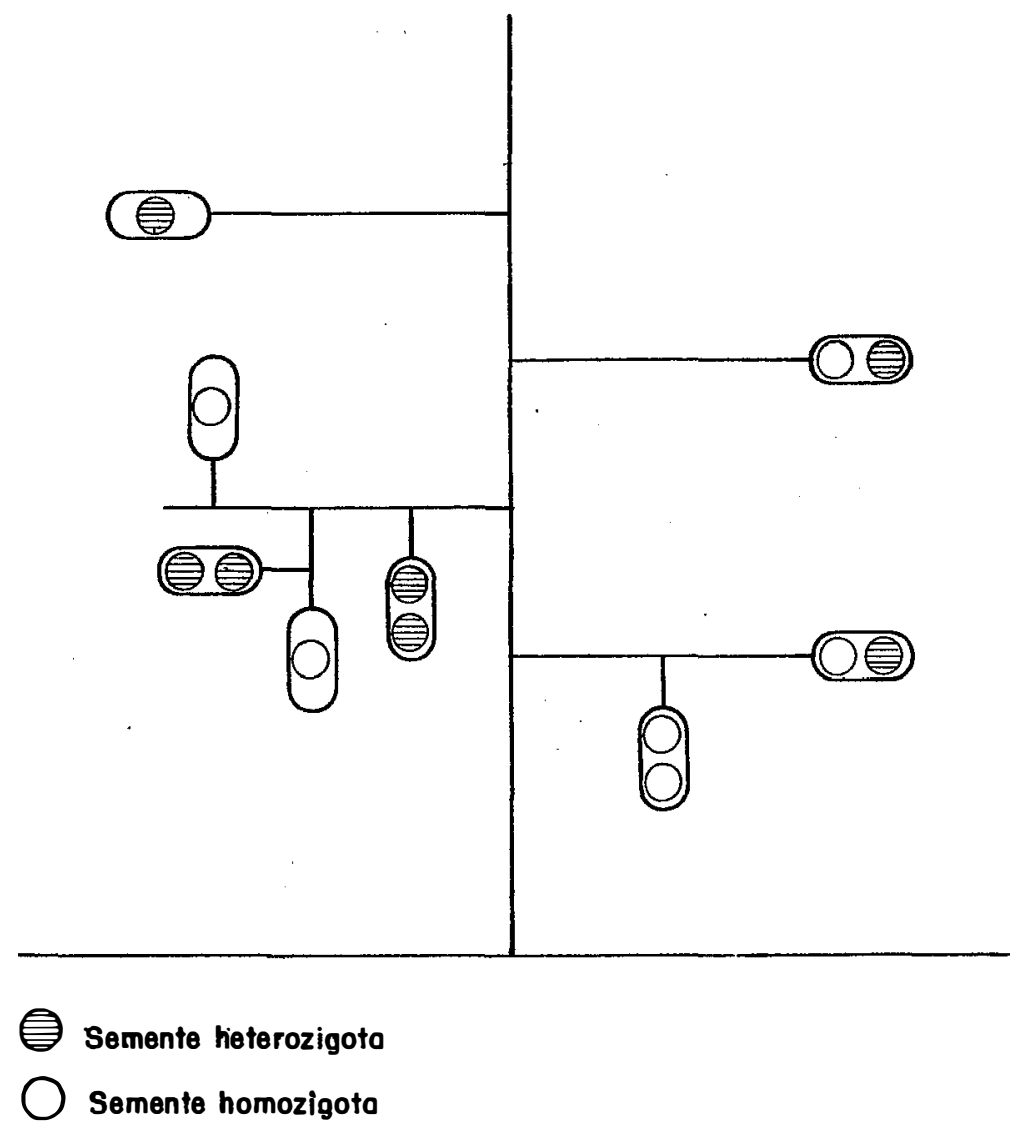

FIGURA 18 - Representação esquemática da análise topogrāifica da planta M no 3.24, mostrando sementes $\mathrm{M}_{2}$ heterozigotas e homozigotas dominantes para o caráter mutante hipocótilo verde. 


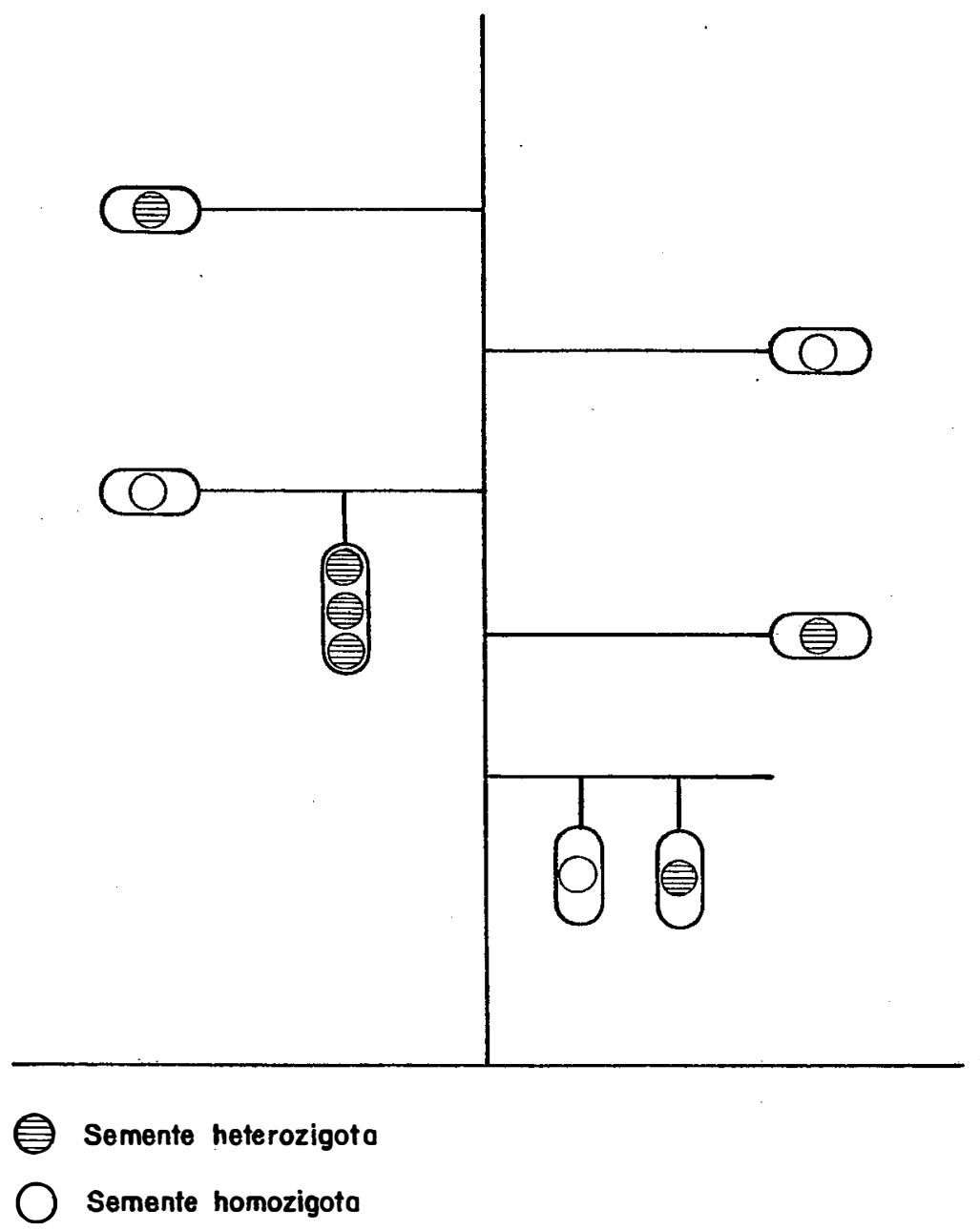

FIGURA 19 - Representação esquemática da anālise topográfica da planta M no 5.05, mostrando sementes $M_{2}$ heterozigotas e homozigotas dominantes, para o carāter mutante hipocótilo verde. 


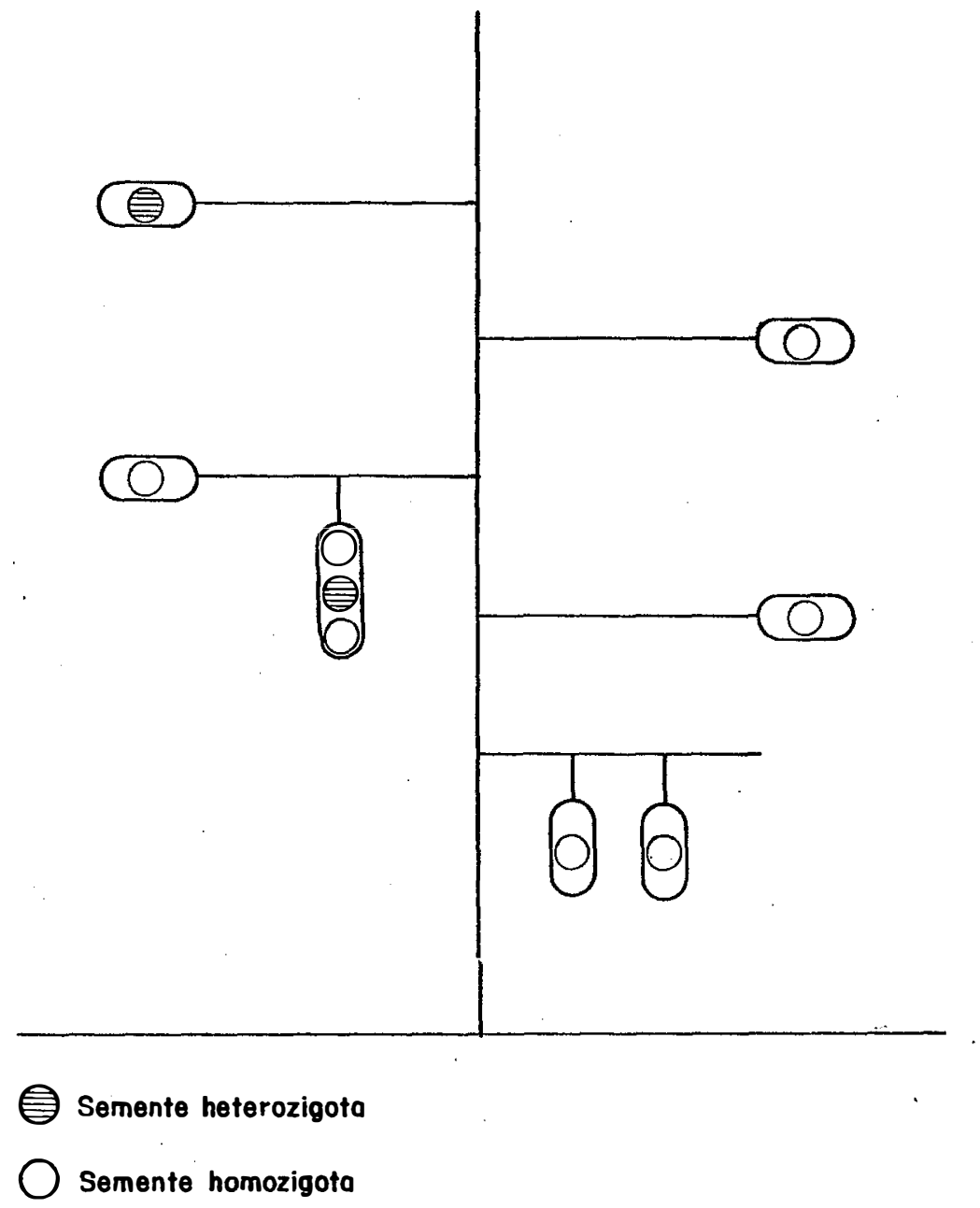

FIGURA 20 - Representação eșquemática da anālise topográfica da planta $M_{1}$. no 5.05, mostrando sementes $\mathrm{M}_{2}$ heterozigotas e homozigotas dominantes, para o caráter mutante hipocótilo verde-escuro. 


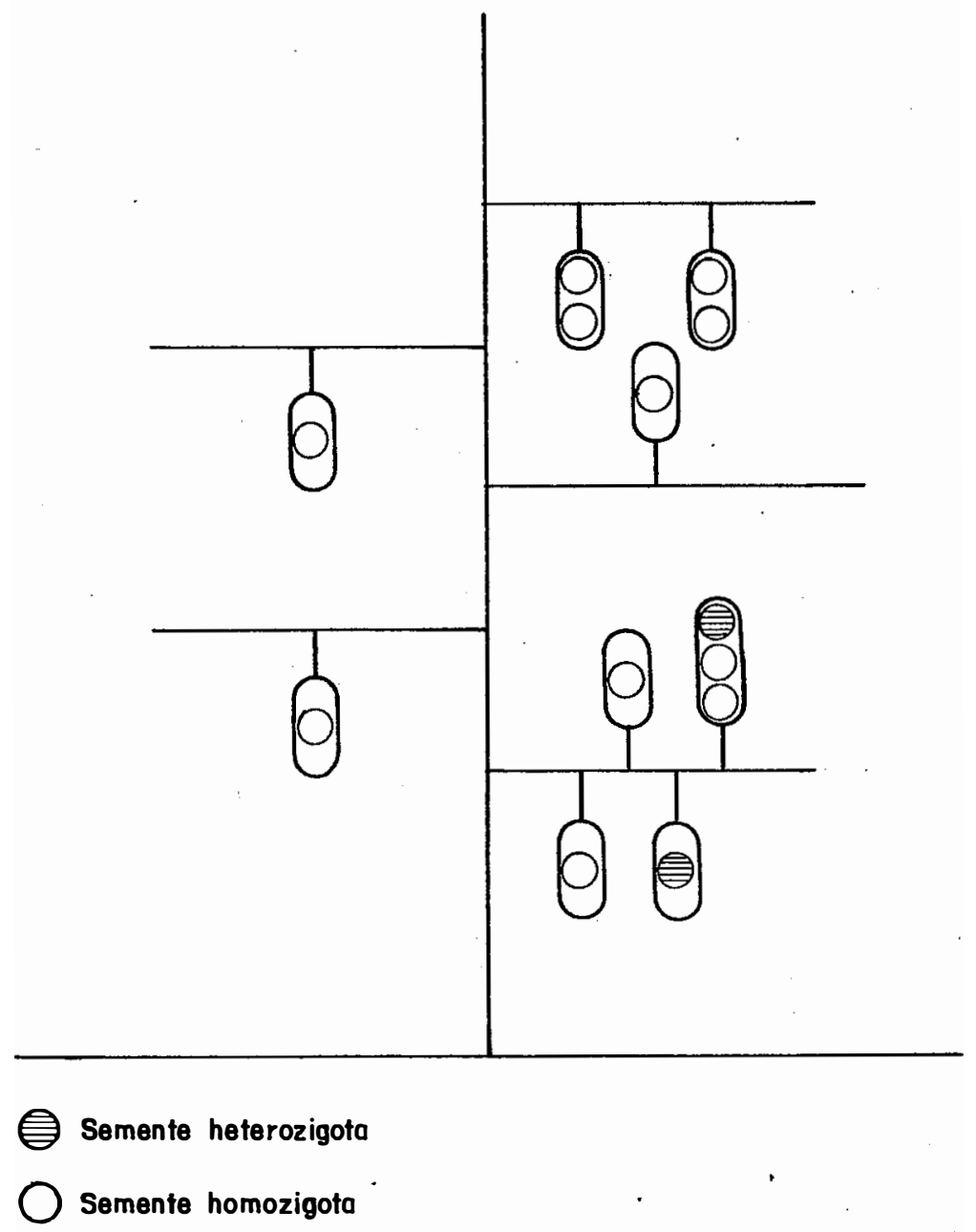

FIGURA 21 - Representação esquemática da anālise topogrā́ica da planta M no 5.14, mostrando sementes $\mathrm{M}_{2}$ heterozigotas e homozigotas dominantes, para o caráter mutante trifoliar. 


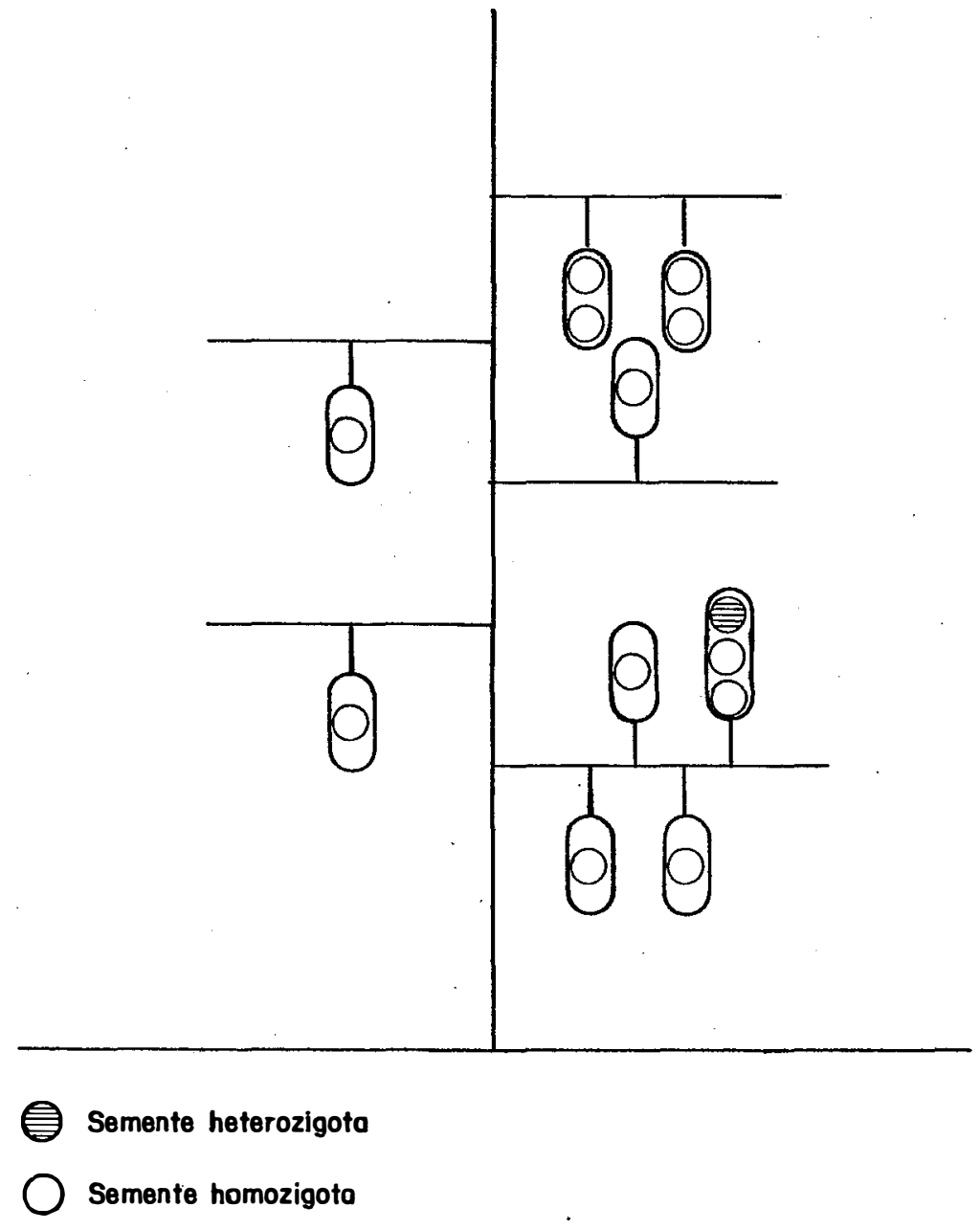

FIGURA 22 - Representação esquemática da anālise topográfica da planta M no 5.14, mostrando sementes $\mathrm{M}_{2}$ heterozigotas e homozigotas dominantes, para o carāter mutante xanta. 


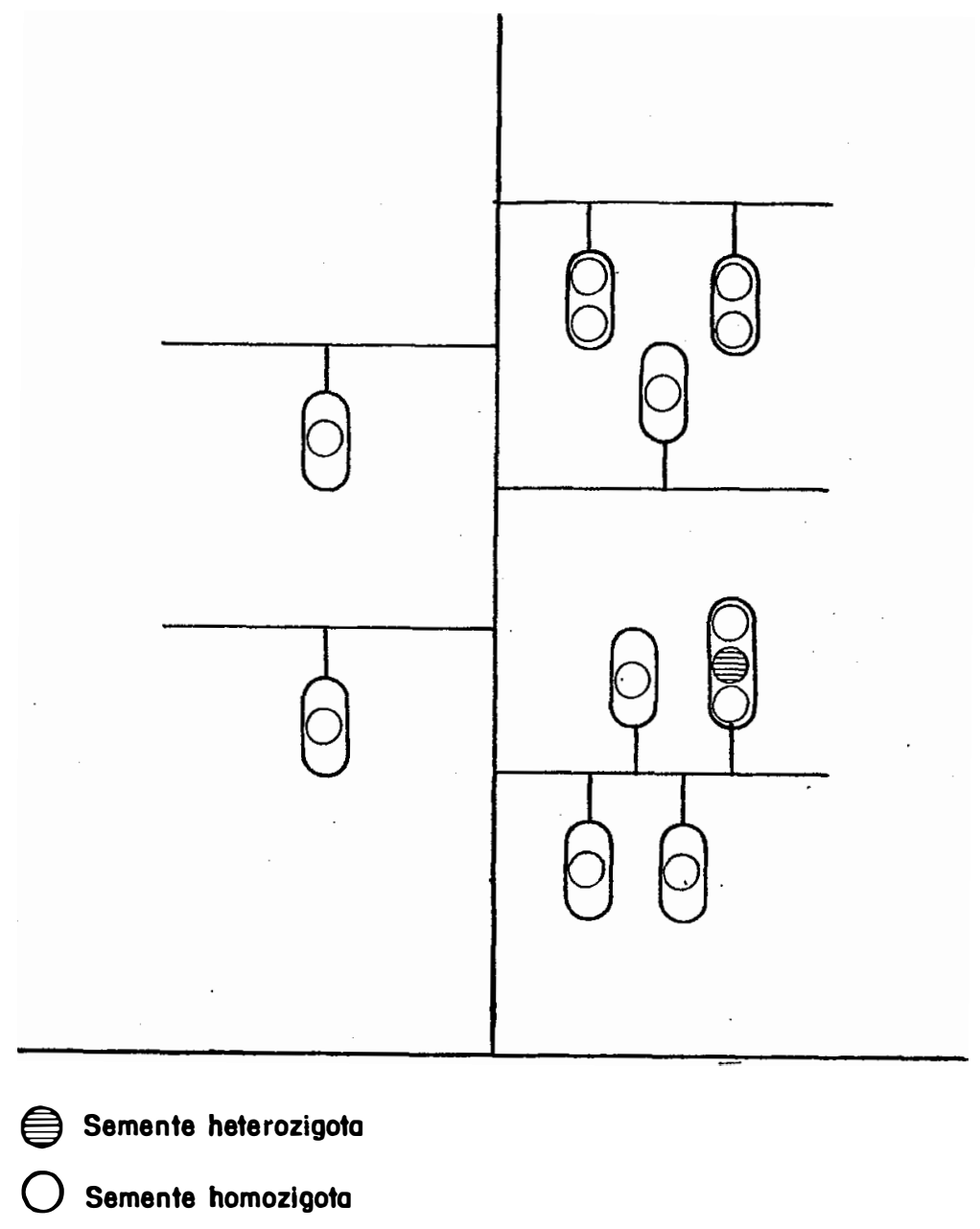

FIGURA 23 - Representação esquemática da anālise topogräfica da planta H $_{1}$ no 5.14, mostrando sementes $\mathrm{M}_{2}$ heterozigotas e homozigotas dominantes para o caráter mutante hipocótilo verde. 


\section{CONCLUSÕES}

Dos resultados obtidos concluiu-se que:

(a) Os caracteres estudados, relacionados à fertilidade das plantas $M_{1}$ foram influenciados diferentemente pelas dosagens de neutrons räpidos aplicados às sementes $\mathrm{M}_{1}$, sendo que os parâmetros vagens/planta e sementes/planta, mostraram-se mais sensĩveis à irradiação.

(b) As sementes $M_{2}$ e $M_{3}$ e plantas $M_{2}$, quanto à germinação e sobrevivência, mostraram um comportamento que sugeriu a existência de um efeito genético ocorrido em $M_{1}$ que, provavelmente, teria sido transmitido às gerações subsequentes. Nessas geraçöes pode-se observar um decréscimo nos valores dos referidos parâmetros, com o aumento da dosagem de radiação, de modo similar aos efeitos fisiológicos concernentes à $M_{1}$.

(c) Dos resultados antagônicos das frequências de mutações determinadas por dois diferentes critérios (considerando-se todos os tipos de mutações observados em cada tratamento e para cada classe de mutaçäo isoladamente), sugere-se que tais frequências serão mais corretamente estima dås, se estudadas separadamente, para cada tipo de mutação. 
(d) Considerando-se os números baixos de plantas $M_{1}$ usadas e, as taxas de segregação obtidas, os resultados encontrados mostraram que as mutações por célula ocorrem em frequências relativamente altas, para os caracteres considerados.

(e) Pela comparação dos tratamentos com 1,0 e 2,0 krad, estes ūltimos foram mais eficientes, causando uma maior taxa de segregação, o que corresponde a uma diminuição no número de células iniciais. Portanto, em experimentos com neutrons rápidos, a dosagem de 2,0 krad permitirā a obtenção de alta frequência de mutantes por célula, a partir de pequeno nümero de sementes.

(f) As células iniciais presentes no embrião das sementes já se encontravam bem diferenciadas no momento dos tratamentos mutagênicos.

(g) $\bar{E}$ provável que mais do que uma célula inicial participe da formação de uma ramificação primária.

(h) Todas as ramificações primärias de uma planta originamse das mesmas células iniciais. 


\section{LITERATURA CITADA}

ANDERSON, E.G.; E. LONGLEY; C.H. LI e K.L. RETHERFORD, 1949. Hereditary effects produced in maize by radiation from the Bikini atomic bomb. I. Studies on seedlings and pollen of the exposed generation. Genetics, Texas, 34: 639-646.

ANDERSON, R.L. e T.A. BANCROFT, 1952. Statistical theory in research. New. York, Mc Graw-Hil1 Book Company, Inc. 399 p.

ANDO, A., 1970. Efeito biológico da combinação de tratamentos com raiosgama, cisteína e algumas substâncias alquilantes sobre sementes de arroz. Piracicaba, ESALQ/USP, 117 p. (Tese de Doutoramento).

AUERBACH, C., 1949. Chemical mutagenesis. Biological Review, Cambridge, $24: 355-391$.

BANDEL, G., 1970. Metodologia da indução de mutações em eucalipto. Pirací caba, ESALQ/USP, 84 p. (Tese de Mestrado).

BIRDIE YEH e M.T. HENDERSON, 1963. Effects from irradiation of rice seed with gamma rays and neutrons on several characteristics of the $R_{1}$ 
generation. Botanical Bulletin of Academia Sinica, Taiwan, 4(2): 90-102.

BLIXT, S.; L. EHRENBERG e 0. GELIN, 1958. Quantitative studies of induced mutations in peas. I. Methodological investigations. Agri Hortique Genetica, Landskrona, $16: 238-250$.

BRIGGS, R.W. e M.J. CONSTANTIN, 1977. Mutagenic radiation: radiation types and radiation sources. In: Manual on Mutation Breeding. Vienna, International Atomic Energy Agency, 2a. ed. p. 33-39.

BRIGGS, R.W. e C.F. KONZAK, 1977. Mutagenic radiation: objects and methods of treatment. In: Monual on Mutation Breeding. Vienna, International Atomic Energy Agency, 2a. ed. p. 33-39.

CALDECOTT, R.S., 1955. The effects of X-rays, $2 \mathrm{MeV}$ electrons, therma 1 neutrons and fast neutrons on dorment seeds of barley. Annals of the New Yor, Academy of Sciences, New York, 59: 514-533.

CALDECOTT, R.S. e L. SMITH, 1952. A study of X-ray-induced chromosomal aberrations in barley. Cytologia, Tokyo, 17: 224-242.

CHOMŌN, J.C.G., 1972. Induccion de mutaciones de color de Semilla con metanosulfonato de etilo en el frijol. Turrialba, Instituto Interamericano de Ciencias Agricolas de 1a OEA, 38 p. (Tese de Mestrado).

Cox, C.D., 1972. Organization of higher chromosomes. Nature, London, New Biol., 239, p. 133.

D'AMATO, F., 1965. Chimera formation in mutagen treated seeds and diplontic selection. In: The Use of Induced Mutations in Plant Breeding. Radiation Botany (Supplement), New York, 5: 303-316.

DEMEREC, M., 1933. The effect of X-ray dosage on sterility and number of lethals in Drosophila melanogaster. Proceedings of the National Academy 
of Science, Washington, 19: 1015-1020.

EHRENBERG, A., 1961. Research on free radicals in enzyme chemistry and in radiation biology. Free radicals in biological systems (BLOIS, M.S., Jr., Ed.) Academic Press, New York, p. 337-350.

EL-KEREDY, M.S. e S.A. ABD-ALLA, 1976. A study of differences in the radiosensitivity of some rice varieties. Egyptian Joumal of Genetics and Cytology, Egito, 5: 48-57.

FARESTVEIT, B., 1968. Flower colour chimeras in glasshouse carnations, Dianthus caryophyllus L. In: Year Book 1969. Royal Veterinary and Agricultural College Copenhagen, p. 19-33.

FEENSTRA, W.J., 1960. Biochemical aspects of seed-coat colour inheritance in Phaseolus vulgaris L. Medelelingen van de Landborwhogeschool Wageningen, Netherlands, 60(2): 1-553.

GAUL, H., 1957. Die verschiedenen bezugssysteme der mutationshaufigkeit bei pflanzen augewendet aud dosis-effektkurven. Z. Pflanzenz, 38:63-76.

GAUL, H., 1959. Uber die Chimarenbildung in Gerstenpflanzen nach Rontgenbestrahlung von Samen. Flora, 147: 207-241.

GAUL, H., 1960. Critical analysis of the methods for determining the mutations frequency after seed treatment with mutagens. Genetica Agraria, Roma, 12: 297-318.

GAUL, H., 1963. Mutationen in der pflanzenziichtung. Z. Pflanzenzuecht., $50: 194-307$.

GENTER, C.F. e H.M. BROWN, 1941. X-ray studies on the field bean. The Journal of Heredity, Washington, 32: 39-44. 
GILES JR., N.H., 1943. Comparative studies of the cytogenetical effects of neutron and X-rays. Genetics, Texas, 28(5): 398-418.

GOTTSCHALK, W., 1977. Fasciated-peas-unusual mutants for breeding and research. Journal of Nuclear Agriculture and Biology, 2: 27-33.

HADJICHRISTODOVLOV, A. e A. DELLA, 1979. High protein barley mutants in Cyprus. Mutation Breeding Newsletter, Vienna, 13: 11-12.

HOLM, G., 1954. Chlorophyll mutations in barley. Acta Agriculturae Scandinavica, Escandināvia, 4: 457-471.

KAMRA, O.P. e H. BRUNNER, 1977. Chemical mutagens: objects and methods of treatment. In: Manual on Mutation Breeding. Vienna, International Atomic Ėnergy Agency, 2a. ed. p. 65-66.

KAPLAN, R.W., 1951. Chromosomen-und faktormutationsraten in Gerstenkornern bei verschiedenartigen Quellungsbehandlunggen oder Kalte wahrend oder nach der Roentgenbestrahlung sowie Dosisfraktionierung. Z. Ind. Abst. Vereb., 83: 347-382.

KAUKIS, K. e L.P. REITZ, 1955. Ontogeny of the Sorghwn inflorescence as revealed by seedling mutants. American Journal of Botany, California, 42: 660-663.

KONZAK, C.F. e W.R. SINGLETON, 1956. The effects of thermal neutron radiation on mutation of endosperm loci in maize. Proceedings of the National Academy of Science, New York, 42: 78-84.

KONZAK, C.F.; R.A. NILAN; J. WAGNER e R.J. FOSTER, 1965. Efficient chemical mutagenesis. In: The Use of Induced Mutations in Plant Breeding. 
Radiation Botany (Supplement), New York, 5: 49-70.

KOOIMAN, H.N., 1931. Monograph on the genetics of Phaseolus (especially P. vulgaris and P. multiflorus). Bibliographia Genetica, Netherlands, 8: 295-413.

KULIEV, A.A., 1978. Comparison of the effects of ethyleneimine and ionizing radiation on cotton seeds. In: Khim. mutagenez i gibridizatsiya, Moscow, p. $134-136$.

LAMPRECHT, H., 1935 a. Zur Genetik von Phaseolus vulgaris. XI. Eine Mutante mit einfachen Blaettern und Ihre Vererbungsweise. Hereditas, Landskrona, 20: 238-250.

LAMPRECHT, H., 1935 b. Zur Genetik von Phaseolus vulgaris. XII. Ube die Vererbung der Bluten-und Stammfarbe. Hereditas, Landskrona, 21: 129-166.

LAMPRECHT, H., 1947. The seven alleles of the genes $R$ of Phaseolus. Agri Hortique Genetica, Landskrona, 5(1-2): 46-64.

LEA, D.E., 1956. Actions of radiations on living cells. 2a. ed. London, Cambridge University Press. 416 p.

MATSUO, T.; H. YAMAGUCHI e A. ANDO, 1958. A comparison of biological effects between thermal neutrons and $\mathrm{X}$-rays on rice seeds. Japanese Journal of Breeding, Japan, 8: 37-45.

MIAH, A.J. e M.A. AWAN, 1971. Induced mutations in rice. In: Rice Breeding with Induced Mutations III. Vienna, International Atomic Energy Agency. p. 77-89. 
MIKAELSEN, K.; I. KISS e K. OSONE, 1968. Some effects of fast neutrons and gamma radiation on rice. In: Neutron Irradiation of Seeds II. Vienna, International Atomic Energy Agency. p. 49-54.

MOH, C.C., 1961. Does a coffee plant develop from one initial cell in the shoot apex of an embryo ? Radiation Botany, New York, 1: 97-99.

MOH, C.C., 1971. Mutation breeding in seed-coat colors of beans (Phaseolus vulgaris L.). Euphytica, Holanda, 20: 119-125.

MOH, C.C. e R.A. NILAN, 1956. Reduced gene transmission in radiationinduced mutant barley. The Journal of Heredity, Washington, 47: 129-131.

MOH, C.C. e J.J. ALAN, 1971. Correlation between seed-coat color and the seedling characters in Phaseolus vulgaris L. Turrialba, Costa Rica, 21: 173-175.

MOHAN RAO, P.K., 1972. The relative merits of the three methods of measuring mutations frequency in barley. Radiation Botany, New York, 12: 323-329.

MONYO, J.H. e T. SUGIYAMA, 1979. Improvement of seed protein in rice through mutation breeding. Tanzania, Fac. Agric., For. \& Veterinary Sci., Dar es Salaam Univ.

MOTTO, M.; G.P. SORESSI e F. SALAMINI, 1975. Mutations frequencies and chimeric formation in Phaseolus vulgaris after EMS treatment of dorment seeds. Radiation Botany, New York, 15: 291-299.

MULLER, H.J., 1927. Artificial transmutation of the gene. Science, Washington, 66: 84-87. 
MüLLER, A.J., 1966. Die Induktion von rezessiven Lethalmutationen durch Athylmethansulfonat bei Arabidopsis. I. Dosis-Effekt-Beziehungen und deren Beinflussung durch die Behandlung sbedingungen. Zuchter, 36 : 201-220.

NAGL, K., 1979. Mutation and breeding work on Vicia faba in Austria. FABIS Newsletter, Vienna, $19(1)$.

NAKAYAMA, R., 1958. Genetical studies on kidney beans (Phaseolus vulgaris L.) II. On the inheritance of hypocotyl color. 1. Bulletin of the Faculty of Agriculture of the Hirosaki University, Japan, 4: 80-87.

NAKAYAMA, R., 1959. Genetical studies on kidney beans (Phaseolus vulgaris L.) IV. On the inheritance of hypocotyl color. 2. Bulletin of the Faculty of Agriculture of the Hirosaki University, Japan, 5: 6-13.

NAKAYAMA, R., 1965. Genetical studies on kidney beans (Phaseolus vulgaris L.). VIII. A new allele at the $C$ locus. Bul.letin of the Faculty of Agriculture of the Hirosaki University, Japan, 11: 55-58.

OLIVER, C.P., 1930. The effect of varying the duration of X-ray treatment upon the frequency of mutation. Science, Washington, 71: 44-46.

PILCH, J., 1977. The response of an inbred line of the rye Rogalinske H to various doses and kinds of radiation. Biuletyn Instytutu Hodowli $i$ Aklimatyzacji Rošlin, 131: 29-40.

PRAKKEN, R., 1942. Inheritance of colours and pod characters in Phaseolus vulgaris L. I. Genetica, Netherlands, 16: 177-296.

PRAKKEN, R., 1959. Induced mutation. Euphytica, Netherlands, 8 : 270-322. 
PRAKKEN, R., 1970. Inheritance of colour in Phaseolus vulgaris L. II. A critical review. Netherlands, Mededelingen Landbouwhogeschool Wageningen, 70-20: 1-38.

SAJō, Z., 1979. High-protein rice selections following mutagenic treatment. Fish Culture Res. Sta. Szarvas, Hungary, p. 202-203.

SARAFI, A., 1974. Use of ionizing radiations for beeding of bean Phaseolus vulgaris L. In: Agronomy Abstracts. Madison.

SARVELLA, P.; R.A. NILAN e C.F. KONZAK, 1962. Relation of embryo structure; node position, tillering and depth of planting to the effects of X-rays in barley. Radiation Botany, New York, 2: 89-108.

SCARASCIA-MUGNOZZA, G.T., 1969. Mutation on sexually propagated plants. Genetica Agraria, Roma, 23(1/4): 187-219.

SHAW, J.K. e J.B. NORTON, 1918. The inheritance of seed-color in garden beans. Bulletin of Massachusetts Agriculture Experiment Station, Massachussets, 135: 59-104.

SMITH, F.L., 1939. A genetic analysis of red seed-coat color in Phaseolus vulgaris L. Hilgardia, 12: 553-621.

SMITH, H.H., 1961. The reactor:as a tool for research in plant sciences and agriculture. In: Programing and Utilizantion of Research Reactors. Londres, Academic Press, p. 425-438.

SMITH, H.H.; J.L. BATEMAN; H. QUASTLER e H.H. ROSSI, 1964. RBE of monoenergetic fast neutrons: cytogenetic effects in maize. In: Symposium Upton, NY, Vienna, International Atomic Energy Agency, p. 233-248. 
STADLER, L.J., 1928 a. Mutations in barley induced by X-rays and radium. Science, Washington, 68: 186-187.

STADLER, L.J., 1928 b. Genetic effects of X-rays in maize. Proceedings of the National Academy of Science, Washington, 14:69-75.

STADLER, L.J., 1930. Some genetic effects of X-rays in plants. Joumal of Heredity, Washington, 21: 3-19.

STADLER, L.J., 1931. The experimental modification of heredity in crop plants. I. Induced chromosomal irregularities. Scientific Agriculture, Otawa, 11: 557-572.

STADLER, L.J., 1942. Some observations on gene variability and spontaneous mutation. The Spragg Memorial Lectures on Plant Breeding, Michigan State College.

STEAGALL, M.L., 1977. Sensitividade à radiação gama de diferentes populações de milho (Zea mays L.).Piracicaba, ESALQ/USP, 149 p. (Dissertação de Mestrado).

STEEL, R.G.D. e J.H. TORRIE, 1960. Principles and procedures of statistics. Mc Graw-Hil1 Book Company, Inc. New York, 481 p.

STOILOV, M. e A. POPOV, 1978. Inducing disease resistant maize mutations via ionizing radiation. Mutation Breeding Newsletter, 12: 4.

TANAKA, T., 1927. BIZZARRIA - a clear case of periclinal chimera. Joumal of Genetics, India, 18: 77-85.

TIMOFEEEFF-RESSOVSKY, N.W.; K.G. ZIMMER e M. DELBRUCK, 1935. Uber die Waturden Genmutation und der Genstruktur. Wachr. Ges. Wiss. Gottingen. Math. physik. k 1, Fachgruppen (6), 1: 196-245.

TULMANN NETO, A., 1979. Obtenção de resistência ou tolerância ao vírus do 
mosaico dourado do feijoeiro (Phaseolus vulgaris L.) através ue indu.. ção de mutação. Piracicaba, ESALQ/USP, 109 p. (Tese de Livre-Docência).

UHLIK, J., 1979. The use of neutron irradiation in the development of new productive varieties of cultivated plants. (Plant Breeding Abstracts, $49(4))$.

VASILEVA, M., 1975. The application of induced mutation in obtaining genetic diversification in peas. Biuletyn Instytutu Hodowli $i$ AkZimatyzacji, Roslin, 128/129: 117-131.

VIEIRA, C., 1967. O feijoeiro comum: culturas, doencas e melhoramento. Viçosa, Imprensa Universitāria da Universidade Rural do Estado de Minas Gerais. 220 p.

YAMAGATA, H. e K. SYAKUDO, 1960. Studies on the utility of artificial mutations in plant breeding. I. X-ray sensitivity of rice and induced aberrant plants in the $\mathrm{x}_{2}$ generation. Japanese Journal of Breeding, Japan, 10: 153-162.

YAMAGUCHI, H., 1962. The chimaeric formation in and $\mathrm{X}_{1}$ panicle after irradiation of dorment rice seed. Radiation Botany, New York, 2: 71-77.

YAMAGUCHI, H., 1980. Texto mimeografado do curso "Fundamentos de Indução de Mutação no Melhoramento de Plantas". Piracicaba, Centro de Energia Nuclear na Agricultura.

YAMAGUCHI, H. e A.J. MIAH, 1964. Mutation mosaicism induced by $\mathrm{X}, \gamma$-rays and ethylene imine in rice. Radioisotopes, Tokyo, 13(6): 472-476. 
YARNELL, S.H., 1965. Cytogenetics of the vegetable crops. IV. Legunes. Botanical Review, New York, 31: 247-330.

YESODA RAJ, A.; A. SUDHARSAN RAJ e G. MADHUSUDANA RAO, 1972. Mutagenic studies of gamma rays on Oryza sativa L. Cytologia, Tokyo, 37: 469-477.

YGLESIAS, G.E., 1964. Estudio sobre el efecto de la densidad de siembra, hābito de crecimiento, calor y tamaño de frijol en los ensayos de variedades. Turṛialba, Costa Rica, Publnes misc. no 22 Inst. Interam. Cienc. Agric. 22: 39-44.

WOO, S.C.; C.M. NG e E.M. TYE, 1971. Induction of mutations in cultivated rice by chemical and physical agents. II. The effect of $\mathrm{M}_{1}$ damage and $\mathrm{M}_{2}$ mutations. Botanical Bulletin of Academia Sinica, Taiwan, 12(2): 66-73. 